\title{
Nuclear genetic variation across the range of ponderosa pine (Pinus ponderosa): Phylogeographic, taxonomic and conservation implications
}

\author{
Kevin M. Potter ${ }^{1}$ - Valerie D. Hipkins ${ }^{2} \cdot$ Mary F. Mahalovich $^{3} \cdot$ Robert E. Means ${ }^{4}$
}

Received: 15 August 2014 /Revised: 12 January 2015 / Accepted: 24 March 2015

(C) Springer-Verlag Berlin Heidelberg (outside the USA) 2015

\begin{abstract}
Ponderosa pine (Pinus ponderosa) is among the most broadly distributed conifer species of western North America, where it possesses considerable ecological, esthetic, and commercial value. It exhibits complicated patterns of morphological and genetic variation, suggesting that it may be in the process of differentiating into distinct regional lineages. A robust analysis of genetic variation across the ponderosa pine complex is necessary to ensure the effectiveness of management and conservation efforts given the species' large distribution, the existence of many isolated disjunct populations, and the potential susceptibility of some populations to climate change and other threats. We used highly polymorphic nuclear microsatellite markers and isozyme markers from 3113 trees in 104 populations to assess genetic variation and structure across the geographic range of ponderosa pine. The results reveal pervasive inbreeding and patterns of genetic diversity consistent with the hypothesis
\end{abstract}

Communicated by S. N. Aitken

This article is part of the Topical Collection on Gene Conservation

Electronic supplementary material The online version of this article (doi:10.1007/s11295-015-0865-y) contains supplementary material, which is available to authorized users.

Kevin M. Potter

kpotter@ncsu.edu

1 Department of Forestry and Environmental Resources, North Carolina State University, Research Triangle Park, NC 27709, USA

2 National Forest Genetics Laboratory, USDA Forest Service, Placerville, CA 95667, USA

3 Genetic Resource Program, Northern, Rocky Mountain, Southwestern and Intermountain Regions, USDA Forest Service, Moscow, ID 83843, USA

4 Bureau of Land Management Wyoming, Cheyenne, WY 82009, USA that ponderosa existed in small, as-yet-undetected Pleistocene glacial refugia north of southern Arizona and New Mexico. The substructuring of genetic variation within the species complex was consistent with its division into two varieties, with genetic clusters within varieties generally associated with latitudinal zones. The analyses indicate widespread gene flow and/or recent common ancestry among genetic clusters within varieties, but not between varieties. Isolated disjunct populations had lower genetic variation by some measures and greater genetic differentiation than main-range populations. These results should be useful for decision-making and conservation planning related to this widespread and important species.

Keywords Biogeography - Gene conservation · Inbreeding · Isozymes $\cdot$ Microevolution $\cdot$ Microsatellites

\section{Introduction}

Ponderosa pine (Pinus ponderosa Douglas ex Lawson) is among the most widely distributed conifers in western North America (Critchfield and Little 1966), spanning approximately $20^{\circ}$ of latitude, from southern Arizona and New Mexico to southern British Columbia, and $24^{\circ}$ of longitude, from coastal California to central Nebraska (Little 1971; Farjon 1984). It is a species with extensive ecological, esthetic, and commercial importance and is a component of many forest types in western North America south of the boreal forest (Oliver and Ryker 1990). Ponderosa pine also exhibits conflicting geographic patterns of trait variation that, when combined with its nearly complete absence from the Pleistocene paleoecological record (Anderson 1989; Van Devender et al. 1987), create confusion about its recent phylogeographic history and about the proper taxonomic treatment of subgroups within the species complex. 
Given that ponderosa pine exists in a broad variety of edaphic conditions occurring from sea level to $3050 \mathrm{~m}$ of elevation (Oliver and Ryker 1990), its extensive geographic variation in several adaptive traits is not surprising. These traits include cold hardiness (Wells 1964; Read 1980; Rehfeldt 1993), growth (Read 1980, 1983; Van Haverbeke 1986; Squillace and Silen 1962; Wells 1964; Wright et al. 1969; Rehfeldt 1990, 1991, 1993), needle and cone morphology (Weidman 1939; Haller 1965; Read 1980; Squillace and Silen 1962; Wells 1964; La Farge 1975; Rehfeldt 1999a; Rehfeldt et al. 1996), disease resistance (Hoff 1988), and monoterpene composition (Smith 1977; Smith et al. 1969; Sturgeon 1979). Patterns of variation in these traits, which often conflict with each other, indicate that ponderosa pine encompasses a complex group of evolutionary units (Moritz 1994) that may be in the process of differentiating into multiple species (Wang 1977; Jaramillo-Correa et al. 2009) or, at least, into distinct regional lineages (Potter et al. 2013).

The species is often described as consisting of two varieties (Little 1979): P. ponderosa var. ponderosa Laws. (Pacific ponderosa pine), which exists from southern California to British Columbia and inland to Idaho and Montana; and P. ponderosa var. scopulorum Engelm. (Rocky Mountain ponderosa pine), which exists in the interior Rocky Mountains. Some taxonomists have further subdivided these two varieties in response to finer-scale morphological variation, with taxonomic treatments that are often in conflict (Conkle and Critchfield 1988; Callaham 2013a, b). Taxonomic confusion in the ponderosa pine complex has not been resolved by protein marker and monoterpene studies, which have generated contradictory results. Genetic distances based on allozyme allele frequencies, for example, indicated close genetic relationships among populations in var. ponderosa and var. scopulorum (Niebling and Conkle 1990; Conkle and Critchfield 1988), while xylem resin monoterpene characteristics were similar between races across the two varieties (Smith 1977) but differed between races of the Pacific variety (Smith 1977; Sturgeon 1979). Studies using molecular data arguably have been more informative. A recent study using chloroplast simple sequence repeat (cpSSR) loci found support for the existence of three operational taxonomic units (OTUs) within the Pacific variety and two OTUs within the Rocky Mountain variety (Wofford et al. 2014). An analysis of a mitochondrial DNA intron minisatellite region, meanwhile, detected ten distinct haplotypes geographically structured in a way corresponding with the division between the Pacific and Rocky Mountain varieties, but otherwise indicating a complex phylogeographic history not revealed by other genetic and morphological data or by the sparse paleoecological record (Potter et al. 2013).

While such deep-time analyses are important, we need a better understanding of the effects of more recent events and processes shaping the genetic structure and variation of ponderosa pine given the complexity of the topography and climate of western North America. Specifically, the modern distributions of temperate species like ponderosa pine, and the patterns of evolutionary relationships and genetic diversity within them, have been forged in large part by the periodic glacial episodes of the late Quaternary period, during which ice sheets advanced and retreated on an approximately 40 , 000-year cycle (Hewitt 2000). Many species weathered the periods of ice sheet advancement in lower-latitude refugia (Provan and Bennett 2008; Hewitt 2000), with spread in subsequent periods of rapid climate change from those refugia (Lascoux et al. 2004; McLachlan et al. 2005; Pearson 2006). A better understanding of these biogeographic processes in ponderosa pine should inform appropriate taxonomic treatments of subgroups within the species complex. Species range-wide analyses using polymorphic, codominant nuclear markers such as microsatellites (e.g., Dvorak et al. 2009; Potter et al. 2012; Boys et al. 2005) and allozymes (e.g., Gibson and Hamrick 1991; Jorgensen and Hamrick 1997; Schmidtling and Hipkins 1998) can be used for the inference of locations of glacial refugia for tree species and of hypothesized routes of post-Pleistocene colonization (e.g., Potter et al. 2012; O'Connell et al. 2008; Heuertz et al. 2004). Such phylogeographic studies using molecular markers typically examine (1) whether distinct lineages exhibit spatial structuring associated with putative refugial areas and colonization routes (Hewitt 1996), because isolation within distinct refugia is expected to result in genetic differentiation and drift (Provan and Bennett 2008), and (2) whether populations currently nearer to putative refugial areas encompass greater genetic diversity than those colonized from the refugia (Comes and Kadereit 1998; Taberlet et al. 1998).

A robust analysis of genetic structure and diversity across the ponderosa pine complex is particularly important to ensure the effectiveness of existing ex situ and in situ conservation efforts given the species' large natural distribution, the existence of many isolated disjunct populations (Little 1971) that may possess unique adaptive characteristics and may be at particular risk of genetic degradation (Slatkin 1987; Jaramillo-Correa et al. 2009), and the fact that portions of the range may be susceptible to climate change (Rehfeldt et al. 2006). It may, in fact, be necessary to prioritize ponderosa pine populations for conservation actions, including seed archiving and silvicultural treatments, because of the potential effects of climate change; bark beetle outbreaks across western North America (Chapman et al. 2012; Meddens et al. 2012), which have been exacerbated by warmer climate conditions (Mitton and Ferrenberg 2012); and changing fire regimes (Whitlock et al. 2003; Littell et al. 2009). In this context, the effective and efficient conservation of ponderosa pine genetic diversity will require better understanding of range-wide population genetic structure as well as the distribution of genetic variation within and among 
populations, the occurrence of rare alleles, and the levels of inbreeding (Eriksson et al. 1993).

We used seven highly polymorphic nuclear microsatellite markers and 19 isozyme markers to assess genetic variation and structure across the geographic range of ponderosa pine. We collected and processed samples from 3113 trees from 104 populations with three objectives: (1) to assess regional patterns in genetic variation to better understand the recent phylogeographic history of the species, (2) to evaluate the genetic variation within isolated disjunct populations, and (3) to assess whether patterns of genetic variation are consistent with current varietal and racial designations within the species. The results of these analyses should be useful for the management and conservation of this widespread and important species in the face of climate change and other threats such as increased insect and disease outbreaks and changing fire regimes.

\section{Methods}

\section{Sample collection and DNA isolation}

As with a previous analysis of mitochondrial DNA variation in ponderosa pine (Potter et al. 2013), this study encompasses a total of 3113 trees across the species range, representing 104 populations (Table 1, Fig. 1). Where possible, the sampling was limited to mature trees that were at least $100 \mathrm{~m}$ apart. The focus of the study was on trees located in populations that were established with natural regeneration before 1900 and with no evidence of reforestation activities through the sample collection date. A branch tip 7.6-12.7 cm in length and containing a dormant terminal bud and healthy needles attached to the stem was collected from each tree. Samples were kept cool on frozen gel packs until shipped to the National Forest Genetics Laboratory (NFGEL) in Placerville, California for DNA extraction. Genomic DNA for all samples was extracted from needles for the microsatellite analysis using the DNEasy 96 Plant Kit (Qiagen, Chatsworth, California, USA). DNA concentrations were determined using a Gemini XPS Microplate Spectrofluorometer (Molecular Devices, Sunnyvale, California, USA) with PicoGreen dsReagent (Invitrogen, Carlsbad, California, USA). Dormant terminal bud tissue from each branch tip was used for the isozyme analysis.

All but four populations encompassed at least 25 trees, enough to accurately estimate allele frequencies in a microsatellite analysis (Hale et al. 2012). Two populations incorporated fewer than 20 samples; one of these (Grass Creek, \#75), contained only ten mature trees, all included in the study. The second was Saguaro National Park (\#66), where sampling was halted because of dangerous weather conditions. The study includes the two oldest known living ponderosa pines, located in the Wah Wah Mountains of western Utah (\#52); the oldest tree is estimated to be 930 years old (Kitchen 2010). The racial assignment of each population (Table 1) generally follows that of Conkle and Critchfield (1988), who proposed two main races within var. ponderosa and two within var. scopulorum. (See Potter et al. 2013 for general distributions of the races.) To avoid confusion between varietal common names (Pacific for var. ponderosa and Rocky Mountain for var. scopulorum) and the racial designations of Conkle and Critchfield (1988), we label the main var. ponderosa races as Pacific Coast and North Plateau, and the var. scopulorum races as Northern Rocky Mountain and Southwestern. Additionally, we treat Washoe pine as a race within var. ponderosa, although this is commonly treated as a separate species (Pinus washoensis H.L. Mason \& Stockw.). The Babbit Peak (\#16) and Mount Rose (\#17) populations consist of stands identified by Critchfield and Little (1966) as being Washoe pine, but appear to include trees with $P$. ponderosa-like morphology (Rehfeldt 1999b). Two other populations (Saguaro National Park, \#66, and Whitetail Trail, \#71) are located within the range of Pinus arizonica Engelm., but do not co-occur with that species. $P$. arizonica was formerly considered a variety of ponderosa pine, but has important morphological differences (Peloquin 1984; Perry 1991; Rehfeldt 1999a) that have elevated its status in most taxonomic treatments of North American pines. Populations were classified as isolated disjuncts if they are located more than $25 \mathrm{~km}$ from the nearest distributional area greater than $1000 \mathrm{~km}^{2}$, as defined by Little (1971). The control group for the genetic analyses consisted of ten Coulter pines (Pinus coulteri D. Don), collected from a provenance trial at the Institute of Forest Genetics in Placerville, California. Coulter pine appears to fall into a clade closely related to ponderosa pine and its nearest relatives (Willyard et al. 2009).

\section{Microsatellite analysis}

To select a set of microsatellite markers for this study, we evaluated 38 microsatellite primer pairs at NFGEL for usefulness in assessing ponderosa pine genetic variation and structure. Of these, 32 were developed from Pinus taeda L. (Liewlaksaneeyanawin et al. 2004), and six were developed from Pinus contorta Doug. (Lesser et al. 2012). Each primer set was screened across a set of 30 samples from throughout the ponderosa pine distribution (two from each of 15 populations). We identified a final set of seven loci that yielded polymorphic and consistently amplified fragments (Table 2). Two P. contorta primer pairs were described by Lesser et al. (2012), while the remaining five primer pairs were described by Elsik et al. (2000) and Elsik and Williams (2001), and were found by Liewlaksaneeyanawin et al. (2004) to demonstrate crossspecific amplification and polymorphism in hard-pine species other than P. taeda. The data for these seven nuclear microsatellite loci were generated across the 3113 ponderosa pine and ten Coulter pine samples. PCR amplification for locus PtTX2146 was achieved in $10 \mu \mathrm{l}$ reaction volumes and 
Table 1 Location, sample size, coordinates, elevation, varietal and racial designation, disjunct versus interior range location ${ }^{\mathrm{a}}$, and source for the 104 populations included in the genetic analyses of ponderosa pine

\begin{tabular}{|c|c|c|c|c|c|c|c|c|}
\hline Pop. & Location, state & $n$ value & Lat. (N) & Long. (W) & Elev. (m) & Variety & Race & Source \\
\hline 1 & Larabee Valley, CA & 30 & 40.43 & -123.68 & 738 & pond & $\mathrm{PC}$ & BLM \\
\hline 2 & Applegate Valley West, OR & 33 & 42.29 & -123.28 & 533 & pond & $\mathrm{PC}$ & BLM \\
\hline 3 & Eugene, OR & 26 & 43.92 & -123.13 & 313 & pond & NP & $\mathrm{BLM} / \mathrm{CE}$ \\
\hline 4 & Hoadley Peaks North, CA & 30 & 40.69 & -122.75 & 1413 & pond & $\mathrm{PC}$ & BLM \\
\hline 5 & Monarch Mountain, CA & 31 & 40.59 & -122.57 & 747 & pond & $\mathrm{PC}$ & NPS \\
\hline 6 & Fort Lewis, $\mathrm{WA}^{\mathrm{a}}$ & 30 & 47.11 & -122.50 & 91 & pond & NP & DOD \\
\hline 7 & Klamath River Canyon, OR & 30 & 42.06 & -122.08 & 1017 & pond & $\mathrm{PC}$ & BLM \\
\hline 8 & Pothole, OR & 30 & 42.95 & -121.88 & 1413 & pond & NP & USFS \\
\hline 9 & Lava Beds, CA & 30 & 41.70 & -121.57 & 1551 & pond & $\mathrm{PC}$ & NPS \\
\hline 10 & Henry W. Coe State Park, $\mathrm{CA}^{\mathrm{a}}$ & 32 & 37.19 & -121.55 & 908 & pond & $\mathrm{PC}$ & CalSP \\
\hline 11 & Lassen, CA & 34 & 40.53 & -121.54 & 1679 & pond & $\mathrm{PC}$ & NPS \\
\hline 12 & Modoc, OR & 30 & 42.97 & -121.39 & 1836 & pond & NP & USFS \\
\hline 13 & Adobe West, OR & 30 & 42.00 & -121.00 & 1481 & pond & NP & BLM \\
\hline 14 & Wenatchee, WA & 30 & 47.60 & -120.43 & 1036 & pond & NP & USFS \\
\hline 15 & Lost Forest, $\mathrm{OR}^{\mathrm{a}}$ & 30 & 43.38 & -120.32 & 1370 & pond & NP & BLM \\
\hline 16 & Madeline Plains, $\mathrm{CA}^{\mathrm{a}}$ & 30 & 40.86 & -120.11 & 1722 & pond & $\mathrm{PC}$ & BLM \\
\hline 17 & Babbitt Peak, CA & 30 & 39.61 & -120.11 & 2624 & pond & WP & USFS \\
\hline 18 & Mount Rose, NV & 30 & 39.34 & -119.88 & 2317 & pond & WP & USFS \\
\hline 19 & Yosemite, CA & 30 & 37.54 & -119.65 & 1260 & pond & $\mathrm{PC}$ & NPS \\
\hline 20 & Sheldon, NV & 30 & 41.83 & -119.64 & 2002 & pond & NP & FWS \\
\hline 21 & Potato Flat, OR & 30 & 43.77 & -119.45 & 1615 & pond & NP & USFS \\
\hline 22 & Sequoia, CA & 30 & 36.77 & -119.09 & 1376 & pond & $\mathrm{PC}$ & USFS \\
\hline 23 & Red Wash Canyon, NV & 33 & 38.40 & -119.07 & 2028 & pond & $\mathrm{PC}$ & USFS \\
\hline 24 & Alamo Mountain, $\mathrm{CA}^{\mathrm{a}}$ & 31 & 34.67 & -118.96 & 2243 & pond & $\mathrm{PC}$ & USFS \\
\hline 25 & Umatilla, OR & 30 & 44.97 & -118.87 & 1158 & pond & NP & USFS \\
\hline 26 & Wassuk Range, $\mathrm{NV}^{\mathrm{a}}$ & 30 & 38.41 & -118.66 & 1988 & pond & $\mathrm{PC}$ & USFS \\
\hline 27 & Bishop Creek, $\mathrm{CA}^{\mathrm{a}}$ & 30 & 37.30 & -118.53 & 1972 & pond & $\mathrm{PC}$ & USFS \\
\hline 28 & Bobsled, OR & 30 & 45.69 & -118.26 & 1401 & pond & NP & USFS \\
\hline 29 & Charlton Flats, $\mathrm{CA}^{\mathrm{a}}$ & 30 & 34.30 & -118.01 & 1634 & pond & $\mathrm{PC}$ & USFS \\
\hline 30 & Wallowa-Whitman, OR & 29 & 45.13 & -117.68 & 1341 & pond & NP & USFS \\
\hline 31 & Strawberry Peak, CA & 30 & 34.23 & -117.21 & 1815 & pond & $\mathrm{PC}$ & USFS \\
\hline 32 & Mineral Ridge, ID & 30 & 47.62 & -116.68 & 733 & pond & NP & BLM \\
\hline 33 & Nez Perce, ID & 30 & 45.45 & -115.92 & 1268 & pond & NP & USFS \\
\hline 34 & Lee Canyon, $\mathrm{NV}^{\mathrm{a}}$ & 30 & 36.33 & -115.66 & 2420 & scop & NRM & Private \\
\hline 35 & Kyle Canyon, NVª & 30 & 36.26 & -115.61 & 2137 & scop & NRM & USFS \\
\hline 36 & Red Rock Canyon, NV & 30 & 36.12 & -115.48 & 1189 & scop & NRM & BLM \\
\hline 37 & Grant Range, $\mathrm{NV}^{\mathrm{a}}$ & 29 & 38.44 & -115.44 & 2174 & scop & NRM & BLM \\
\hline 38 & Sheep Range High, $N^{a}$ & 30 & 36.59 & -115.22 & 2314 & scop & NRM & FWS \\
\hline 39 & Sheep Range Low, NV & 30 & 36.63 & -115.11 & 1981 & scop & NRM & FWS \\
\hline 40 & Seaman Range, NV & 27 & 38.07 & -115.10 & 2271 & scop & NRM & BLM \\
\hline 41 & North Pahroc Range, NV & 29 & 37.68 & -114.95 & 2118 & scop & NRM & BLM \\
\hline 42 & Glacier, $\mathrm{MT}^{\mathrm{a}}$ & 30 & 48.83 & -114.32 & 1108 & pond & NP & NPS \\
\hline 43 & Snake Range, $\mathrm{NV}^{\mathrm{a}}$ & 30 & 39.01 & -114.25 & 2313 & scop & NRM & NPS \\
\hline 44 & Bitterroot, MT & 30 & 45.83 & -114.14 & 1676 & pond & NP & USFS \\
\hline 45 & Beaver Dam State Park, NV & 30 & 37.51 & -114.09 & 1608 & scop & NRM & NevSP \\
\hline 46 & Mormon Gulch, $\mathrm{UT}^{\mathrm{a}}$ & 32 & 37.97 & -114.03 & 2225 & scop & NRM & USITLA \\
\hline 47 & Toms Creek, UT ${ }^{\mathrm{a}}$ & 29 & 39.87 & -113.88 & 2438 & scop & NRM & BLM \\
\hline 48 & Hualapai Mtns, $A Z^{\mathrm{a}}$ & 30 & 35.06 & -113.87 & 1868 & scop & SW & BLM \\
\hline
\end{tabular}


Table 1 (continued)

\begin{tabular}{|c|c|c|c|c|c|c|c|c|}
\hline Pop. & Location, state & $n$ value & Lat. $(\mathrm{N})$ & Long. (W) & Elev. (m) & Variety & Race & Source \\
\hline 49 & Black Rock Mountains, $\mathrm{AZ}^{\mathrm{a}}$ & 31 & 36.80 & -113.75 & 2103 & scop & NRM & BLM \\
\hline 50 & Steamboat Mountain, UT ${ }^{\mathrm{a}}$ & 32 & 38.09 & -113.69 & 1951 & scop & NRM & BLM \\
\hline 51 & Big Hole National Battlefield, MT & 31 & 45.65 & -113.66 & 1952 & pond & NP & NPS \\
\hline 52 & Wah Wah Mountains, UT ${ }^{\mathrm{a}}$ & 24 & 38.60 & -113.55 & 2467 & scop & NRM & BLM \\
\hline 53 & Dunningan Gulch, MT & 26 & 46.96 & -113.53 & 1118 & pond & NP & BLM \\
\hline 54 & Blackfoot River-Dupont, MT & 25 & 47.00 & -113.32 & 1155 & pond & NP & BLM \\
\hline 55 & Sinbad Spring, $\mathrm{UT}^{\mathrm{a}}$ & 30 & 39.38 & -113.32 & 2387 & scop & NRM & BLM \\
\hline 56 & Brown's Gulch, $\mathrm{MT}^{\mathrm{a}}$ & 32 & 46.35 & -113.27 & 1804 & pond & NP & BLM \\
\hline 57 & Big Hole River/Valley, $\mathrm{MT}^{\mathrm{a}}$ & 36 & 45.64 & -112.96 & 1612 & pond & NP & BLM \\
\hline 58 & Marcum Mountains, MT & 30 & 46.94 & -112.89 & 1301 & pond & NP & BLM \\
\hline 59 & Ranch Canyon, UT & 31 & 38.40 & -112.81 & 2164 & scop & NRM & BLM \\
\hline 60 & Kaibab, $A Z^{\mathrm{a}}$ & 27 & 35.83 & -112.08 & 1981 & scop & SW & USFS \\
\hline 61 & Boulder Mountains, MT & 30 & 46.51 & -112.03 & 1701 & scop & NRM & BLM \\
\hline 62 & Coconino, $\mathrm{AZ}$ & 29 & 35.00 & -111.67 & 2134 & scop & SW & USFS \\
\hline 63 & Big Belt Mountains, $\mathrm{MT}^{\mathrm{a}}$ & 30 & 46.33 & -111.27 & 1473 & scop & NRM & BLM \\
\hline 64 & Little Belt Mountains, MT & 30 & 46.89 & -111.20 & 1676 & scop & NRM & BLM \\
\hline 65 & Henry Mountains, UT $^{\mathrm{a}}$ & 30 & 38.07 & -110.84 & 2417 & scop & NRM & BLM/USITLA \\
\hline 66 & Saguaro National Park, $\mathrm{AZ}^{\mathrm{a}}$ & 12 & 32.15 & -110.52 & 1859 & scop & SW & NPS \\
\hline 67 & White Rocks Canyon, UT & 30 & 40.62 & -109.94 & 2274 & scop & NRM & USFS \\
\hline 68 & Bridger Creek, $\mathrm{MT}^{\mathrm{a}}$ & 30 & 45.65 & -109.77 & 1349 & scop & NRM & BLM \\
\hline 69 & Book Cliffs, UT ${ }^{\mathrm{a}}$ & 30 & 39.56 & -109.41 & 2109 & scop & NRM & BLM \\
\hline 70 & Judith Mountains, MT & 30 & 47.13 & -109.36 & 1463 & scop & NRM & BLM \\
\hline 71 & Whitetail Trail, $\mathrm{AZ}^{\mathrm{a}}$ & 20 & 32.03 & -109.32 & 1920 & scop & SW & NPS \\
\hline 72 & Apache-Sitgreaves, AZ & 70 & 34.05 & -109.31 & 2444 & scop & SW & USFS \\
\hline 73 & Douglas Mountain, $\mathrm{CO}^{\mathrm{a}}$ & 30 & 40.58 & -108.68 & 2195 & scop & NRM & BLM \\
\hline 74 & Little Rocky Mountains, MT & 30 & 47.90 & -108.63 & 1224 & scop & NRM & BLM \\
\hline 75 & Grass Creek, WYa & 10 & 43.90 & -108.58 & 1750 & scop & NRM & BLM \\
\hline 76 & Boggy Draw, CO & 31 & 37.51 & -108.48 & 2310 & scop & SW & USFS \\
\hline 77 & Sawmill Mesa, CO & 30 & 38.49 & -108.40 & 2560 & scop & SW & USFS \\
\hline 78 & Square S Gulch, $\mathrm{CO}^{\mathrm{a}}$ & 31 & 39.97 & -108.29 & 1980 & scop & NRM & BLM \\
\hline 79 & Shepard Recreation Site, MT & 30 & 46.06 & -108.29 & 1031 & scop & NRM & BLM \\
\hline 80 & Big Horn Mountain, WY & 32 & 44.13 & -107.38 & 1866 & scop & NRM & BLM \\
\hline 81 & San Juan-Pagosa, CO & 29 & 37.30 & -107.10 & 2408 & scop & SW & USFS \\
\hline 82 & Eight-Mile, CO & 30 & 37.17 & -106.98 & 2438 & scop & SW & USFS \\
\hline 83 & Seminoe Mountains, $\mathrm{WY}^{\mathrm{a}}$ & 30 & 42.17 & -106.94 & 2186 & scop & NRM & BLM \\
\hline 84 & Sparks, CO & 30 & 37.27 & -106.90 & 2377 & scop & SW & USFS \\
\hline 85 & Billy Creek, WY & 29 & 44.10 & -106.85 & 2327 & scop & NRM & BLM \\
\hline 86 & Lower Willow Creek, CO & 33 & 37.66 & -106.60 & 2675 & scop & NRM & USFS \\
\hline 87 & Rawlins, $W Y^{\mathrm{a}}$ & 30 & 41.02 & -106.48 & 2469 & scop & NRM & USFS \\
\hline 88 & Stove Gulch, WYa & 30 & 43.25 & -106.38 & 1687 & scop & NRM & Private/BLM \\
\hline 89 & Four Elk, CO & 30 & 38.90 & -106.21 & 2659 & scop & NRM & BLM \\
\hline 90 & North Inlet, CO & 30 & 40.26 & -105.80 & 2675 & scop & NRM & NPS \\
\hline 91 & Ojito, NM & 30 & 36.14 & -105.72 & 2466 & scop & SW & USFS \\
\hline 92 & Red Feather Lakes, CO & 30 & 40.79 & -105.58 & 2552 & scop & NRM & USFS \\
\hline 93 & Walker Canyon Bottom, NM & 30 & 32.97 & -105.54 & 2257 & scop & SW & USFS \\
\hline 94 & Wild Basin, $\mathrm{CO}$ & 30 & 40.22 & -105.54 & 2505 & scop & NRM & NPS \\
\hline 95 & Mescalero Apache Reservation, NM & 30 & 33.07 & -105.38 & 1942 & scop & SW & BIA \\
\hline 96 & Deer Haven, CO & 30 & 38.61 & -105.38 & 2458 & scop & NRM & BLM \\
\hline 97 & Casper, WY & 32 & 42.37 & -105.35 & 1951 & scop & NRM & USFS \\
\hline
\end{tabular}


Table 1 (continued)

\begin{tabular}{|c|c|c|c|c|c|c|c|c|}
\hline Pop. & Location, state & $n$ value & Lat. (N) & Long. (W) & Elev. (m) & Variety & Race & Source \\
\hline 98 & Vedauwoo, WY & 30 & 41.19 & -105.29 & 2353 & scop & NRM & USFS \\
\hline 99 & Stonewall, CO & 30 & 37.14 & -105.05 & 2486 & scop & NRM & Private \\
\hline 100 & Rampart Range, $\mathrm{CO}$ & 20 & 38.95 & -104.94 & 2848 & scop & NRM & USFS \\
\hline 101 & Eddy, $\mathrm{NM}^{\mathrm{a}}$ & 30 & 32.15 & -104.76 & 1813 & scop & SW & USFS \\
\hline 102 & Black Hills, SD & 35 & 44.20 & -103.82 & 1945 & scop & NRM & USFS \\
\hline 103 & Black Mesa West, $\mathrm{OK}^{\mathrm{a}}$ & 30 & 36.83 & -102.96 & 1393 & scop & SW & OkSLT \\
\hline 104 & Niobrara Valley Preserve, NE & 30 & 42.78 & -100.08 & 755 & scop & NRM & $\mathrm{TNC}$ \\
\hline
\end{tabular}

Variety: pond, var. ponderosa, scop, var. scopulorum. Race: PC Pacific Coast, NP North Plateau, WP Washoe, NRM Northern Rocky Mountain, SW Southwestern. Source: BLM Bureau of Land Management, CE City of Eugene, NPS National Park Service, DOD Department of Defense, USFS USDA Forest Service, CalSP California State Parks, FWS U.S. Fish and Wildlife Service, NevSP Nevada State Parks, USITLA Utah School Institutional Trust Land Administration, BIA Bureau of Indian Affairs, OkSLT Oklahoma School Land Trust, TNC The Nature Conservancy

${ }^{a}$ Disjunct population

included $10 \mathrm{~mm}$ TRIS $\mathrm{HCl} \mathrm{pH} 8.3,50 \mathrm{~mm} \mathrm{KCl}, 1.7 \mathrm{~mm}$ $\mathrm{MgCl}_{2}, 200 \mu \mathrm{m}$ of each dNTP, $0.4 \mu \mathrm{m}$ of each primer, $5 \mathrm{ng}$ of DNA template, and 0.2 units of HotStar Taq DNA Polymerase from QIAGEN (Valencia, CA). Amplifications for all other loci were conducted in $10 \mathrm{ul}$ reaction volumes that included $10 \mathrm{~mm}$ TRIS $\mathrm{HCl} \mathrm{pH} \mathrm{8.3,50} \mathrm{mm} \mathrm{KCl,} 2.5 \mathrm{~mm} \mathrm{MgCl}$, $65 \mu \mathrm{m}$ of each dNTP, $1 \mu \mathrm{m}$ of each primer, $5 \mathrm{ng}$ of DNA template, and 0.25 units of HotStar Taq DNA Polymerase. A touchdown cycling program, used for all loci, consisted of an activation step $\left(94^{\circ} \mathrm{C}\right.$ for $\left.15 \mathrm{~min}\right)$ followed first by 4 cycles of denaturation at $94{ }^{\circ} \mathrm{C}$ for $30 \mathrm{~s}$, annealing at $60^{\circ} \mathrm{C}$ for $30 \mathrm{~s}$, and extension at $72{ }^{\circ} \mathrm{C}$ for $1 \mathrm{~min}$, and then four more cycles using a lower annealing temperature of $57^{\circ} \mathrm{C}$. A final set of $30 \mathrm{cy}-$ cles were conducted using $30 \mathrm{~s}$ denaturation at $94{ }^{\circ} \mathrm{C}, 30 \mathrm{~s}$ annealing at $55{ }^{\circ} \mathrm{C}$, and $1 \mathrm{~min}$ extension at $72{ }^{\circ} \mathrm{C}$. A final extension at $72{ }^{\circ} \mathrm{C}$ was included for $7 \mathrm{~min}$. Each forward primer was labeled with a fluorescent tag for visualization on an ABI Prism 3130xl capillary electrophoresis system (Applied Biosystems, Foster City, CA) following a 1:50 dilution of amplification product. Peaks were sized and binned, and then alleles were called using GeneMarker 1.95 (SoftGenetics, State College, PA), with GeneScan-500 ROX as an internal size standard for each sample. Visual checks were also performed on all electrophoresis products.

\section{Isozyme analysis}

Approximately $50 \mathrm{mg}$ of dormant vegetative bud tissue per tree was submerged in each of three microtiter plate wells containing $150 \mu \mathrm{l}$ of a $0.1 \mathrm{M}$ Tris- $\mathrm{HCl}(\mathrm{pH} 8.0)$ extraction buffer, with $10 \%(w / v)$ polyvinylpyrrolidone- $40,10 \%$ sucrose, $0.17 \%$ EDTA (Na2 salt), $0.15 \%$ dithiothreitol, $0.02 \%$ ascorbic acid, $0.10 \%$ bovine albumin, $0.05 \%$ NAD, $0.035 \%$ NADP, and $0.005 \%$ pyridoxal-5-phosphate (United States Department of Agriculture Forest Service 2012; Pitel and Cheliak 1984). Samples were frozen at $-70{ }^{\circ} \mathrm{C}$. On the day of electrophoresis, samples were thawed and ground, and the extracts were absorbed onto 3-mm-wide wicks prepared from Whatman 3MM chromatography paper.

The methods of sample preparation and electrophoresis follow the general methodology of Conkle et al. (1982), with some modifications (United States Department of Agriculture Forest Service 2012). All enzymes were resolved on $11 \%$ starch gels. A lithium borate electrode buffer ( $\mathrm{pH}$ 8.3) was used with a Tris citrate gel buffer (pH 8.3) (Conkle et al. 1982) to resolve alcohol dehydrogenase (ADH), leucine aminopeptidase (LAP), phosphoglucomutase (PGM), and phosphoglucose isomerase (PGI). A sodium borate electrode buffer $(\mathrm{pH} 8.0)$ was used with a Tris citrate gel buffer $(\mathrm{pH}$ 8.8) (Conkle et al. 1982) to resolve glutamate-oxaloacetate transaminase (GOT), catalase (CAT), superoxide dismutase (SOD), and uridine diphosphoglucose pyrophosphorylase (UGPP). A morpholine citrate electrode and gel buffer (pH 6.1) (United States Department of Agriculture Forest Service 2012) were used to resolve phosphogluconate dehydrogenase (6PGD) and malate dehydrogenase $(\mathrm{MDH})$, and a $\mathrm{pH} 8.0$ morpholine citrate electrode and gel buffer were used to resolve isocitrate dehydrogenase (IDH) and shikimate dehydrogenase (SKD). Enzyme stain recipes follow USDA Forest Service (2012). For quality control, $12 \%$ of individuals were run and scored twice. Gels were photographed for future reference.

Fig. 1 The proportion, within each ponderosa pine population, of inferred ancestry from the genetic clusters inferred using Structure 2.3.3 (Pritchard et al. 2000), for a two genetic clusters and $\mathbf{b}$ nine genetic clusters. The distribution of Pinus ponderosa var. ponderosa is represented in cross-hatched blue, and the distribution of Pinus ponderosa var. scopulorum in single-hatched orange. See Table 1 for population information. Population-level proportions of four and five genetic clusters are shown in Online Resource 2 
(a)

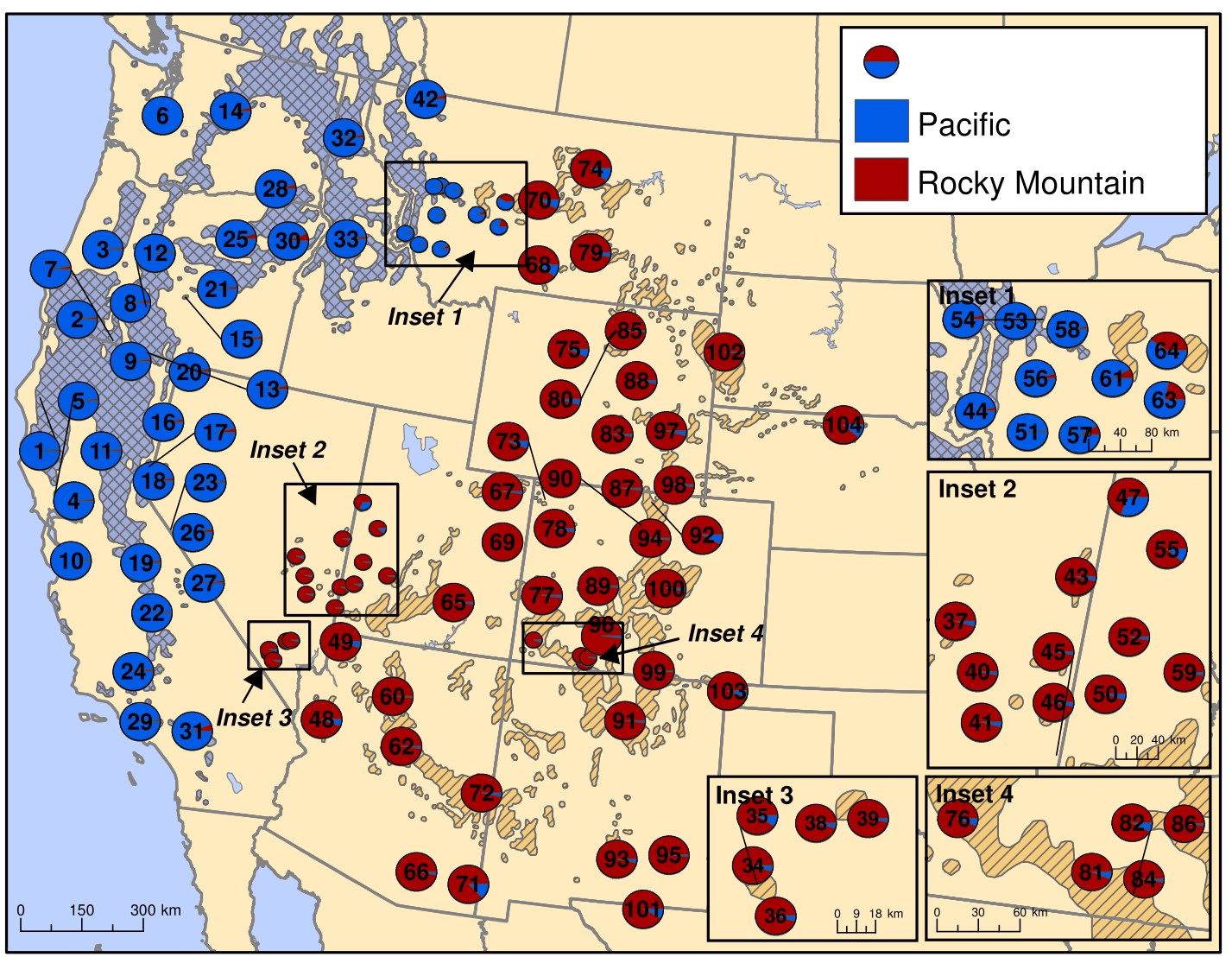

(b)

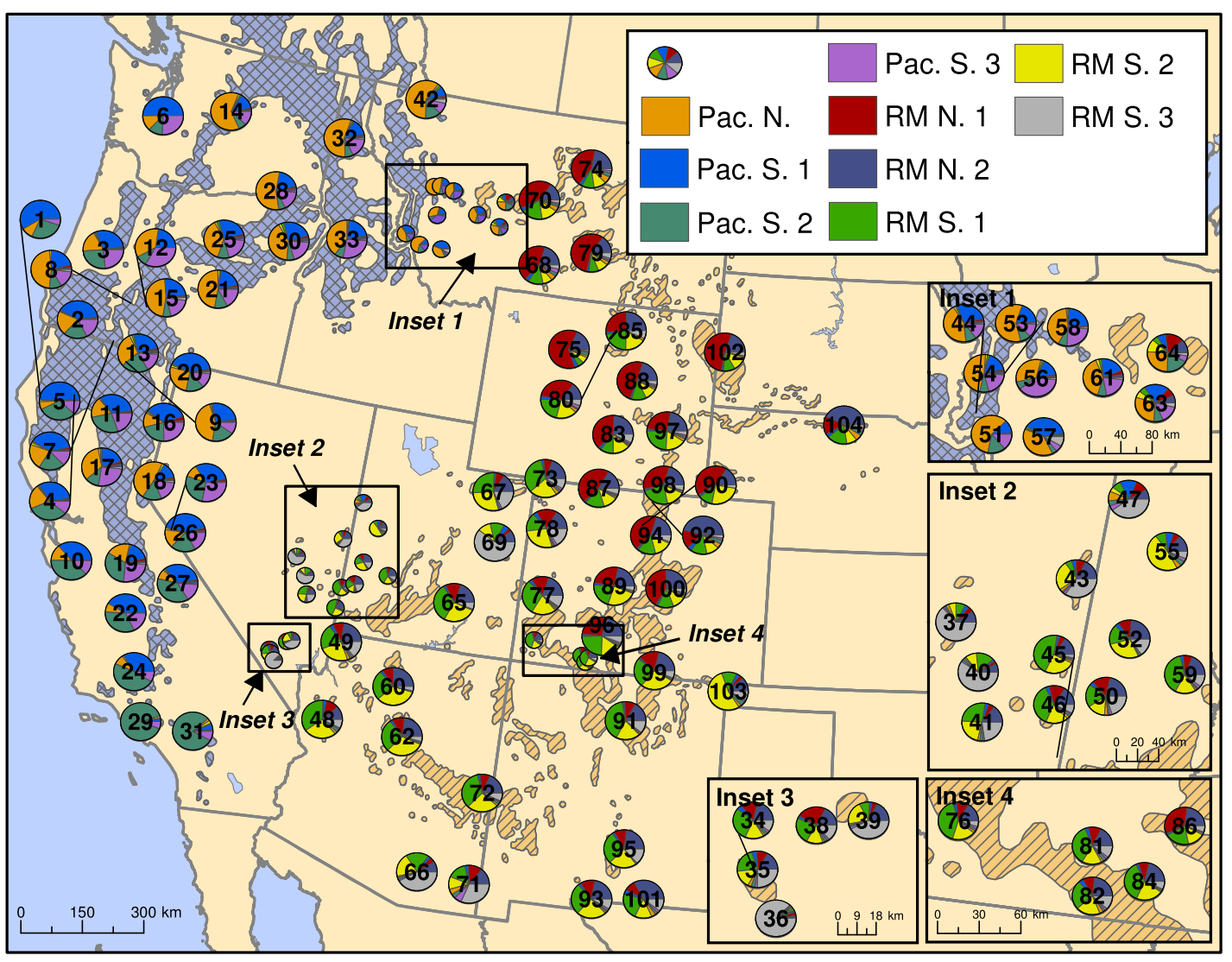




\section{Statistical analyses}

\section{Bayesian assignment tests}

To infer the number and composition genetic clusters of ponderosa pine, we used STRUCTURE 2.3.3 (Pritchard et al. 2000) to conduct an admixture analysis of the microsatellite data, assuming uncorrelated allele frequencies, with 20 , 000 burn-in replicates and 70,000 total sweeps. We ran the model 20 times for each possible maximum number of clusters $(\mathrm{K})$ from 1 to 12 . The $\Delta \mathrm{K}$ statistic of Evanno et al. (2005) revealed a dominant peak at $\mathrm{K}=2$, with smaller peaks at $\mathrm{K}=3$, 4 , and 5, suggesting the possibility of substructure occurring within each of two strongly differentiated clusters (Evanno et al. 2005). We exported the results to CLUMPP version 1.1.2 (Jakobsson and Rosenberg 2007) to generate an averaged Q matrix of individual posterior cluster probabilities for $\mathrm{K}=2,4,5$, and 9, using the greedy algorithm and the $\mathrm{G}^{\prime}$ pairwise matrix similarity statistic. We then calculated the proportion of overall genetic cluster presence probability for each population, based on the probability of cluster membership for individuals in the population. We displayed these population-level probability proportions in map form using ArcMap 9.2 (ESRI 2006). We then conducted further analyses based on the results of the $\mathrm{K}=2$ and 9 clustering analyses, assigning each tree to the STRUCTURE-inferred genetic cluster to which it had the highest probability of belonging.

To visualize potential evolutionary relationships among the inferred genetic clusters, we constructed a neighbor-joining (NJ) (Saitou and Nei 1987) phylogram using the SEQBOOT, GENDIST, NEIGHBOR, and CONSENSE components of PHYLIP 3.6 (Felsenstein 2005). We adjusted for null allele frequencies by implementing the maximum likelihood estimator in ML-NullFreq (Kalinowski and Taper 2006). The phylogram was computed from cluster allelic frequencies using chord genetic distance $\left(D_{\mathrm{C}}\right)$ (Cavalli-Sforza and Edwards 1967), which does not require assumptions about the model under which microsatellites mutate and is considered superior to most others in phylogenetic tree topology construction over short spans of evolutionary time (Takezaki and Nei 1996; Libiger et al. 2009). Confidence estimates associated with the topology of the NJ phylogram were determined with 1000 bootstrap replicates.

\section{Genetic variation and differentiation analyses}

Microsatellite and isozyme allele calls were used to conduct separate analyses of genetic variation across loci and at the population level, and to conduct analyses of genetic differentiation for the STRUCTURE-inferred clusters. We used FSTAT version 2.9.3.2 (Goudet 1995) to test for linkage disequilibrium between pairs of loci, based on 420 permutations and adjusted for multiple comparisons. We estimated null allele frequencies across the entire sample pool in FreeNA (Chapuis and Estoup 2007), using the expectation maximization algorithm of Dempster et al. (1977). We used GENEPOP 4.0.10 (Raymond and Rousset 1995) to conduct Fisher's exact tests for Hardy-Weinberg equilibrium for each locus and population, with 100 batches and 1000 iterations, then used the MULTTEST procedure in SAS 9.2 (SAS Institute Inc. 2008) to calculate $q$ values ( $p$ values adjusted for the false discovery rate associated with multiple comparisons).

We used GenAlEx 6.41 (Peakall and Smouse 2006) to calculate mean number of alleles across loci $(A)$, number of unique (private) alleles per population $\left(A_{\mathrm{U}}\right)$, mean number of locally common alleles that are globally rare across the range of the species (occurring in fewer than $25 \%$ of populations $)\left(A_{\mathrm{R}}\right)$, proportion polymorphic loci $(P \mathrm{p})$, observed heterozygosity $\left(H_{\mathrm{O}}\right)$, and expected heterozygosity $\left(H_{\mathrm{E}}\right)$. The values of $H_{\mathrm{E}}$ were used to calculate the effective number of alleles $A_{\mathrm{E}}$ as $1 /\left(1-H_{\mathrm{E}}\right)$ (Jost 2008). We used FSTAT to calculate Weir and Cockerham's (1984) within-population inbreeding coefficient $\left(F_{\text {IS }}\right)$ values across loci and populations. We used FreeNA (Chapuis and Estoup 2007) to estimate amongpopulation $F_{\mathrm{ST}}$ values and pairwise $F_{\mathrm{ST}}$ values between the genetic clusters inferred in STRUCTURE, accounting for estimated microsatellite null frequencies. The significance of these values was based on 1000 bootstrap replicates. We also used FreeNA to calculate pairwise chord genetic distance $\left(D_{\mathrm{C}}\right)$ accounting for estimated null alleles. We calculated mean $D_{\mathrm{C}}$ between each population and every other population as a measure of overall genetic distance. Finally, we used GENEPOP to estimate interpopulation gene flow $(\mathrm{Nm})$ among all populations and among STRUCTURE-inferred genetic clusters under the private allele method (Barton and Slatkin 1986), corrected for sample size.

Using the program SMOGD (Crawford 2010), we calculated per-locus estimates of Jost's D (Jost 2008), $D_{\text {est, }}$ as a measure of genetic differentiation across all populations of ponderosa pine, and as a measure of differentiation between pairs of clusters. We calculated the arithmetic means of $D_{\text {est }}$ across the loci for ponderosa pine and calculated the $95 \%$ confidence interval for this mean using the confidence intervals of each locus from 500 bootstrap replicates.

We used Bottleneck 1.2.02 (Piry et al. 1999) to assess whether ponderosa pine of any sampled populations or inferred genetic clusters had experienced recent population bottlenecks. We used a two-phase model (TPM) of microsatellite mutation with $95 \%$ single-step mutations and $5 \%$ multiplestep changes, and $12 \%$ variance in multistep mutations. Significance of heterozygosity excess or deficiency was evaluated with a one-sided Wilcoxon sign-rank test using 5000 simulation iterations. We reported $p$ values from tests of heterozygosity deficiency $\left(H_{\text {def }}\right)$.

Using the UNIVARIATE procedure in SAS 9.2 (SAS Institute Inc. 2008), we calculated within-group population 
means for several genetic diversity metrics, to compare populations within the two ponderosa pine varieties, and populations that were and were not classified as isolated disjuncts. To test the null hypothesis that there was no significant difference between the means of each pair of groups, we conducted an exact two-sample Wilcoxon rank-sum test using the NPAR1WAY procedure in SAS, with 10,000 Monte Carlo runs generating $p$ values, then employed the MULTTEST procedure to calculate $q$ values. We used the CORR procedure in SAS 9.2 to test for Spearman correlations between the genetic variation metrics and population latitude and elevation, which have been found to be associated with genetic variation in ponderosa pine (Rehfeldt et al. 2014a). To test for population isolation by distance (IBD), we conducted a Mantel test for correlations between matrices of pairwise interpopulation geographic distances and pairwise interpopulation $D_{\mathrm{C}}$ genetic distances, using 9999 permutations in GenAlEx 6.4.

We also used GenAlEx 6.41 to conduct a three-tiered hierarchical analysis of molecular variance (AMOVA) (Excoffier et al. 1992; Huff et al. 1993) to determine the partitioning of diversity among populations, regions, and populations within regions. We conducted this analysis across the entire range with the Pacific and Rocky Mountain varieties treated as regions, and for each of the two varieties, with the races within the varieties treated as regions. The significance of the variance components was determined with 999 permutations.

\section{Results}

\section{Species-level microsatellite and isozyme results}

The seven microsatellite loci averaged 24.86 alleles per locus across the 3113 samples of ponderosa pine, ranging from 11 to 38 alleles at a single locus (Table 2). The isozyme analysis, meanwhile, detected a mean of 3.53 alleles across each of the 19 loci (Online Resource 1). No linkage disequilibrium was apparent between any pairs of microsatellite loci after adjusting the $p$ value for multiple comparisons. The average estimated proportion of null alleles across loci was 0.091 ; whenever possible, analyses accounted for estimated null allele frequencies. Ponderosa pine exhibited moderate microsatellite expected heterozygosity (mean of 0.721 across loci), and exact tests for Hardy-Weinberg equilibrium indicated a significant deficit of heterozygotes for all but two loci. Observed heterozygosity was considerably lower than expected heterozygosity (mean 0.563 ) across most loci. Expected heterozygosity $(0.121)$ was slightly higher than observed heterozygosity (0.102) across the isozyme loci, with all but one locus out of Hardy-Weinberg equilibrium with a significant deficit of heterozygotes. The significantly positive inbreeding coefficients $\left(F_{\mathrm{IS}}\right)$ of 0.096 for microsatellites ( $95 \%$ confidence interval; $0.002-0.180$ ) and 0.184 for isozymes ( $95 \%$ confidence interval; 0.149-0.238) indicate a deficit of heterozygotes and the likely presence of inbreeding.

Estimates of among-population microsatellite and isozyme differentiation using $F_{\mathrm{ST}}$ and $D_{\text {est }}$ differed considerably (Table 2). The $F_{\mathrm{ST}}$ analysis estimated a moderately high amount of genetic differentiation among rather than within populations $\left(F_{\mathrm{ST}}\right.$ across loci $=0.133,95 \%$ confidence interval; 0.099-0.173). $D_{\text {est }}$, meanwhile, suggested greater genetic differentiation, with a mean across loci of 0.340 (95\% confidence interval; 0.331-0.349). For isozymes, $D_{\text {est }}$ was higher, with a mean across loci of 0.048 (95\% confidence interval; $0.045-0.051)$, compared to an $F_{\mathrm{ST}}$ mean of 0.178 (95\% confidence interval; $0.113-0.243)$. Interpopulation gene flow $\mathrm{Nm})$ for the microsatellite data was estimated at 5.19 migrants per generation across all populations, 6.12 for Pacific populations, and 6.19 for Rocky Mountain populations. These were considerably higher than that of the $1.83,1.37$, and $4.61 \mathrm{Nm}$

Table 2 Description of the five Pinus taeda and two Pinus contorta nuclear microsatellite loci used in the study, with measures of genetic variation, inbreeding, deviation from Hardy-Weinberg equilibrium, estimated null allele frequencies, and GenBank accession number for each

\begin{tabular}{lllllllllllllll}
\hline Locus & Species & size range & $A$ & $H_{\mathrm{E}}$ & $H_{\mathrm{O}}$ & $A_{\mathrm{E}}$ & $D_{\mathrm{est}}$ & $F_{\mathrm{ST}}$ & $F_{\mathrm{IS}}$ & HWE & Null & GenBank & Source \\
\hline PtTX2123 & P. taeda & $175-214$ & 14 & 0.593 & 0.470 & 2.45 & 0.244 & 0.204 & -0.001 & ns & 0.064 & AY330131 & Elsik et al. 2000 \\
Pico138 & P. contorta & $125-198$ & 28 & 0.588 & 0.414 & 2.43 & 0.117 & 0.045 & 0.259 & $*$ & 0.136 & not submitted & Lesser et al. 2012 \\
Pico109 & P. contorta & $103-201$ & 36 & 0.869 & 0.599 & 7.61 & 0.531 & 0.130 & 0.197 & $*$ & 0.135 & not submitted & Lesser et al. 2012 \\
PtTX3127 & P. taeda & $117-168$ & 14 & 0.689 & 0.613 & 3.21 & 0.311 & 0.192 & -0.106 & ns & 0.035 & AY330142 & Elsik and Williams 2001 \\
PtTX2128 & P. taeda & $197-254$ & 11 & 0.529 & 0.414 & 2.12 & 0.174 & 0.172 & 0.058 & $*$ & 0.090 & AY330132 & Elsik et al. 2000 \\
PtTX3030 & P. taeda & $270-394$ & 38 & 0.900 & 0.641 & 9.98 & 0.565 & 0.113 & 0.191 & $*$ & 0.135 & AY330137 & Elsik et al. 2000 \\
PtTX2146 & P. taeda & $129-225$ & 33 & 0.879 & 0.792 & 8.27 & 0.439 & 0.090 & 0.010 & $*$ & 0.043 & AY330133 & Elsik et al. 2000 \\
Total & & & 174 & & & & & 0.133 & 0.096 & $*$ & & & &
\end{tabular}

$A$ alleles per locus, $H_{\mathrm{E}}$, expected heterozygosity, $H_{\mathrm{O}}$, observed heterozygosity, $A_{\mathrm{E}}$, effective alleles, $D_{\text {est }}$, estimate of Jost's $\mathrm{D}, F_{\mathrm{ST}}$ among-population variation accounting for null alleles, $F_{\mathrm{IS}}$ inbreeding coefficient, $H W E$ Hardy-Weinberg exact test of heterozygote deficiency

${ }^{*} q<0.05$ using false discovery rate adjustment; Null: estimated proportion of null alleles (Dempster et al. 1977) 
values derived from the isozymes, resulting potentially not only from gene flow, but also from the higher mutation rate of microsatellite alleles.

\section{Bayesian cluster assignment}

The STRUCTURE analysis revealed the possible existence of genetic substructuring in ponderosa pine. The presence of two genetic clusters was the most strongly supported possibility, but their further division into four, five and nine genetic clusters was also reasonably inferred. The division of the species into two genetic clusters corresponded closely with its division into two varieties (Fig. 1a). The genetic composition of nearly all populations consisted almost entirely of the cluster associated with their variety. Only three populations (\#61, 63, and 64) contained less than a majority of the genetic cluster associated with their variety, all located in the contact zone between the two varieties in western Montana.

When STRUCTURE inferred four total genetic clusters, each variety was divided into a predominantly northern and southern cluster (Online Resource 2). When STRUCTURE inferred five clusters, the division of Pacific populations into two clusters was unchanged, while a new cluster was added in the southern and central regions of the Rocky Mountains (Online Resource 2). The inference of nine clusters divided the Pacific variety into four and the Rocky Mountain variety into five clusters (Fig. 1b). Of the four Pacific clusters, one occurred mainly in the Pacific Northwest and northern California (Pacific North), another along the coast of the Pacific Northwest into central and southern California (Pacific South 1), one mostly in southern and central California (Pacific South 2), and the last in the Sierra Nevada and along the northern edge of the Great Basin (Pacific South 3). Of the five Rocky Mountain clusters, one was most prevalent from southcentral Colorado to central Montana (Rocky Mountain North 1); another along the eastern side of the Rockies and in northern Arizona (Rocky Mountain North 2); two in Arizona and New Mexico north into Utah and western Colorado (Rocky Mountain South 1 and 2); and the last in southern Arizona, Nevada, and Utah (Rocky Mountain South 3).

A consensus NJ phylogram of microsatellite $D_{\mathrm{C}}$ genetic distance among the nine clusters showed high bootstrap support for grouping the five Rocky Mountain genetic clusters (Fig. 2a). The clade of Rocky Mountain genetic clusters was nested within a cascade of Pacific clusters, beginning with the Pacific North cluster $(76.6 \%$ bootstrap support), followed by Pacific South 3 (40.1\%), Pacific South 1 (56.6\%), and Pacific South 2 (100\%). The consensus NJ phylogram based on the isozyme results, meanwhile, showed a more distinct division between the Rocky Mountain and Pacific genetic clusters (Fig. 2b).

Pairwise comparisons of migration $(\mathrm{Nm})$ between microsatellite genetic clusters suggested a high level of historical
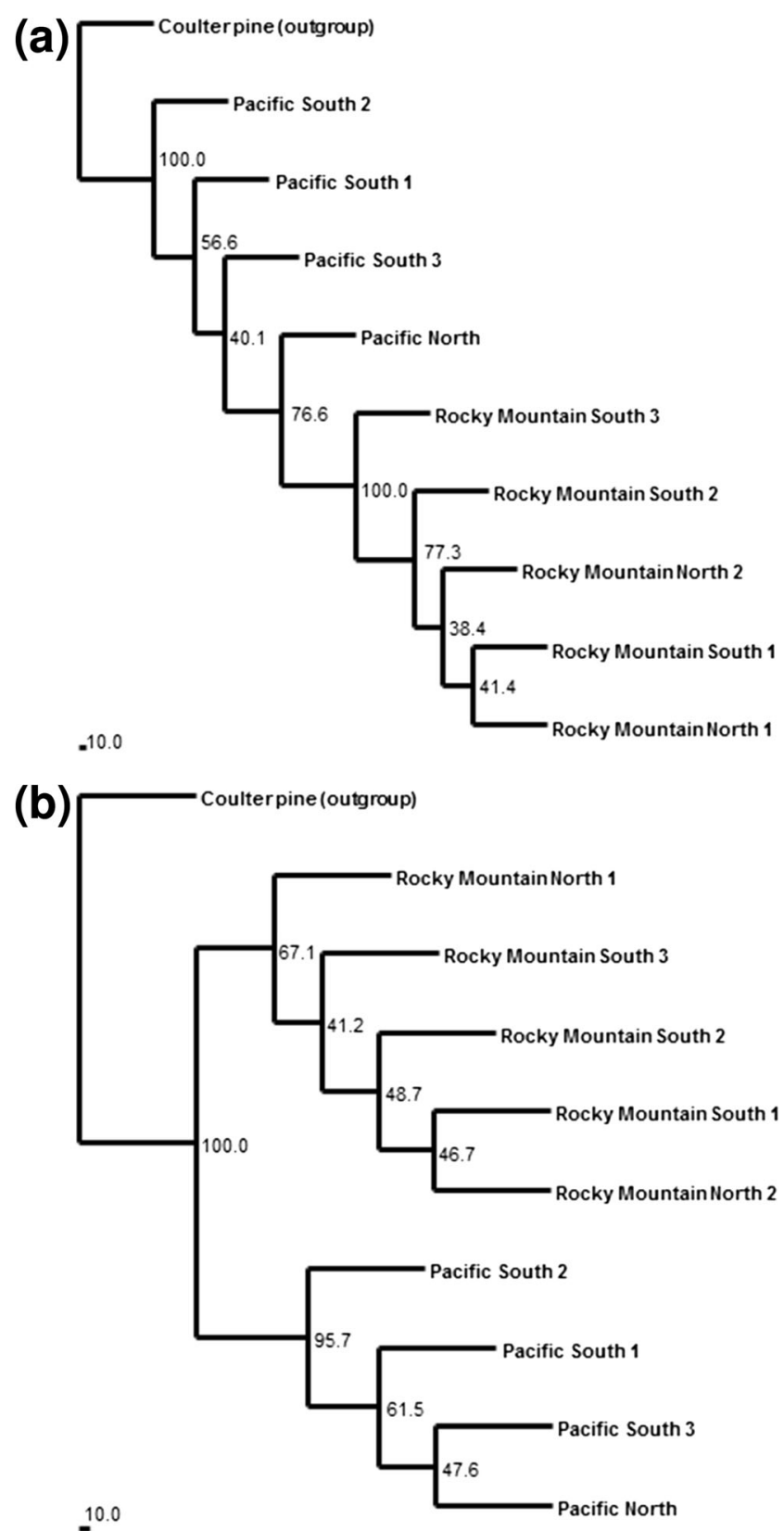

Fig. 2 Consensus neighbor-joining phylogram depicting $D_{\mathrm{C}}$ genetic distance (Cavalli-Sforza and Edwards 1967) among the clusters of ponderosa pine, with Coulter pine as an outgroup, based on a microsatellite data and $\mathbf{b}$ isozyme data. The values represent the percent bootstrap support for the nodes over 1000 replicates

gene flow and/or recent common ancestry between some, but not all, pairs of clusters within ponderosa pine varieties (Table 3). Estimated gene flow (and/or the likelihood of recent common ancestry) was generally small between clusters in different ponderosa pine varieties (mean pairwise $\mathrm{Nm}=2.48$ ). Lower levels of gene flow (and/or likelihoods of recent common ancestry) were estimated among Pacific clusters (mean pairwise $\mathrm{Nm}=4.94$ ) than among Rocky Mountain clusters (mean pairwise $\mathrm{Nm}=10.25$ ). 
Table 3 Pairwise gene exchange estimates and genetic differentiation among the nine ponderosa pine genetic clusters, based on seven polymorphic microsatellite loci

\begin{tabular}{lcllllllll}
\hline & PN & PS1 & PS2 & PS3 & RMN1 & RMN2 & RMS1 & RMS2 & RMS3 \\
\hline Pacific North & & $0.041 / 0.044$ & $0.062 / 0.052$ & $0.032 / 0.064$ & $0.300 / 0.175$ & $0.298 / 0.172$ & $0.315 / 0.191$ & $0.312 / 0.162$ & $0.468 / 0.175$ \\
Pacific South 1 & 15.90 & - & $0.028 / 0.035$ & $0.040 / 0.097$ & $0.387 / 0.216$ & $0.371 / 0.226$ & $0.395 / 0.233$ & $0.399 / 0.205$ & $0.539 / 0.226$ \\
Pacific South 2 & 5.00 & 1.75 & - & $0.076 / 0.075$ & $0.396 / 0.218$ & $0.361 / 0.229$ & $0.406 / 0.233$ & $0.336 / 0.196$ & $0.546 / 0.217$ \\
Pacific South 3 & 1.15 & 1.23 & 4.63 & - & $0.524 / 0.221$ & $0.489 / 0.222$ & $0.529 / 0.233$ & $0.520 / 0.199$ & $0.558 / 0.179$ \\
Rocky Mountain North 1 & 3.80 & 2.59 & 1.02 & 1.74 & - & $0.028 / 0.041$ & $0.042 / 0.059$ & $0.049 / 0.046$ & $0.102 / 0.088$ \\
Rocky Mountain North 2 & 5.55 & 3.50 & 1.38 & 1.88 & 12.55 & - & $0.030 / 0.065$ & $0.043 / 0.039$ & $0.102 / 0.076$ \\
Rocky Mountain South 1 & 4.26 & 3.42 & 0.50 & 1.99 & 15.21 & 13.48 & - & $0.019 / 0.051$ & $0.089 / 0.081$ \\
Rocky Mountain South 2 & 2.58 & 1.53 & 1.01 & 1.42 & 17.12 & 19.52 & 8.85 & - & $0.094 / 0.064$ \\
Rocky Mountain South 3 & 4.48 & 3.41 & 0.68 & 2.89 & 3.84 & 2.00 & 2.84 & 7.05 & - \\
\hline
\end{tabular}

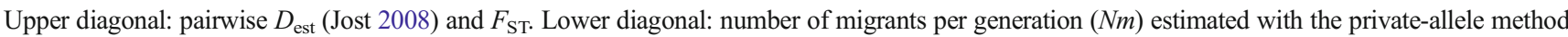

Rocky Mountain clusters all had greater microsatellite allelic richness $(A)$ than Pacific clusters (Table 4) and higher percentages of polymorphic isozyme loci (Online Resource 3). All the genetic clusters were inbred for both microsatellites and isozymes, but the Pacific clusters generally exhibited higher microsatellite inbreeding. The Pacific North and Rocky Mountain South 3 clusters contained the most unique microsatellite alleles (Table 4).

\section{Population-level genetic variation and differentiation}

Ponderosa pine populations averaged 7.37 microsatellite alleles per locus $(A)$ and 2.56 effective alleles per locus $\left(A_{\mathrm{E}}\right)$ (Online Resource 4). In general, populations with the highest microsatellite allelic richness were located along the crest of the Rocky Mountains from Arizona to Montana and in the Sierra Nevada range in California (Fig. 3a). Isozyme $A$, meanwhile, tended to be higher in northern California/southwestern
Oregon, southern New Mexico/eastern Arizona, southern Nevada/southwestern Utah, and northern Colorado/northern Utah (Online Resource 5, Online Resource 6). The populations with the lowest microsatellite $A(\# 29,47,55$, and 75) and isozyme $A$ (\#10, 43, 69, and 75) were isolated disjuncts. With one exception, all populations had $100 \%$ microsatellite loci polymorphism. The proportion of isozyme polymorphic loci $\left(P_{\mathrm{P}}\right)$ across populations was relatively small $(0.47)$, with populations in an arc from northern California through western Montana tending to have higher polymorphism, along with populations scattered throughout the southern Rocky Mountains (Online Resource 6).

Populations containing unique microsatellite alleles tended to occur in southern Rocky Mountain populations (Online Resource 4, Fig. 3b). Across populations, the mean number of locally common alleles that are globally rare (occurring in fewer than $25 \%$ of populations) was 2.63 . Nearly all populations with an average of 3.5 or more rare alleles per locus

Table 4 Measures of genetic variation for each of seven ponderosa pine genetic clusters, based on seven nuclear microsatellite loci

\begin{tabular}{llllllllllll}
\hline Genetic Cluster & $n$ value & $A$ & $A_{\mathrm{U}}$ & $A_{\mathrm{R}}$ & $H_{\mathrm{E}}$ & $H_{\mathrm{O}}$ & $A_{\mathrm{E}}$ & $F_{\mathrm{IS}}$ & HWE & Mean $D_{C}$ & $H_{\text {def }}$ \\
\hline Pacific North & 493 & 15.00 & 4 & 1.14 & 0.642 & 0.564 & 2.79 & 0.122 & $*$ & 0.379 & 0.000 \\
Pacific South 1 & 384 & 14.57 & 0 & 1.14 & 0.588 & 0.523 & 2.43 & 0.112 & $*$ & 0.388 & 0.000 \\
Pacific South 2 & 237 & 14.57 & 2 & 1.14 & 0.631 & 0.541 & 2.71 & 0.144 & $*$ & 0.411 & 0.000 \\
Pacific South 3 & 213 & 14.57 & 2 & 1.00 & 0.704 & 0.592 & 3.38 & 0.161 & $*$ & 0.412 & 0.000 \\
Rocky Mountain North 1 & 383 & 17.43 & 2 & 1.14 & 0.597 & 0.574 & 2.48 & 0.041 & $*$ & 0.368 & 0.000 \\
Rocky Mountain North 2 & 325 & 16.43 & 2 & 1.14 & 0.579 & 0.540 & 2.38 & 0.069 & $*$ & 0.356 & 0.000 \\
Rocky Mountain South 1 & 423 & 16.57 & 3 & 1.29 & 0.581 & 0.579 & 2.39 & 0.005 & $*$ & 0.364 & 0.000 \\
Rocky Mountain South 2 & 370 & 18.00 & 3 & 1.00 & 0.632 & 0.584 & 2.72 & 0.078 & $*$ & 0.361 & 0.000 \\
Rocky Mountain South 3 & 270 & 17.43 & 4 & 1.29 & 0.704 & 0.580 & 3.38 & 0.178 & $*$ & 0.386 & 0.000 \\
Mean & 344 & 16.06 & 2.44 & 1.14 & 0.629 & 0.564 & 2.74 & 0.101 & - & 0.381 & - \\
\hline
\end{tabular}

$A$, mean alleles per locus; $A_{\mathrm{U}}$, unique (private) alleles; $A_{\mathrm{R}}$, mean rare alleles (locally common alleles found in $<25 \%$ of populations); $H_{\mathrm{E}}$, expected heterozygosity; $H_{\mathrm{O}}$, observed heterozygosity; $A_{\mathrm{E}}$, effective number of alleles; $F_{\mathrm{IS}}$, inbreeding coefficient; HWE, Hardy-Weinberg exact test of heterozygote deficiency; Mean DC, mean pairwise chord distance (Cavalli-Sforza and Edwards 1967) with all other populations; $H_{\text {def, }} p$ value for test of heterozygote deficiency

${ }^{*} q<0.05$ using false discovery rate adjustment 
(a)

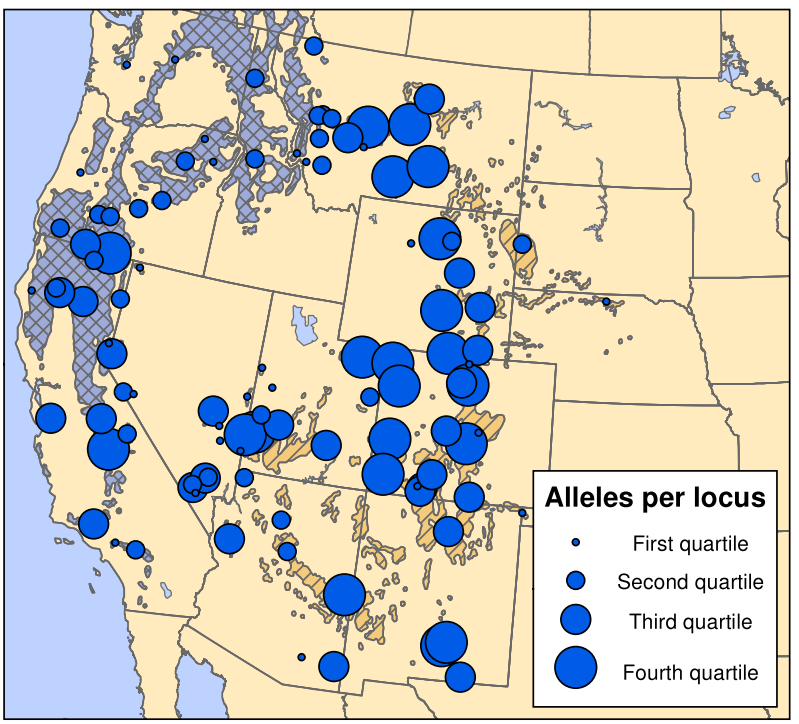

(c)

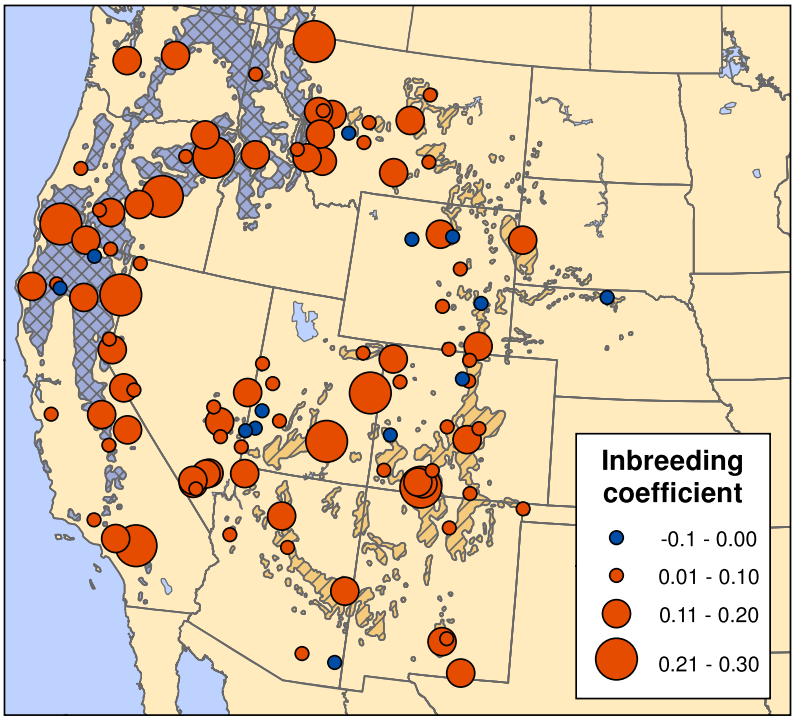

(b)

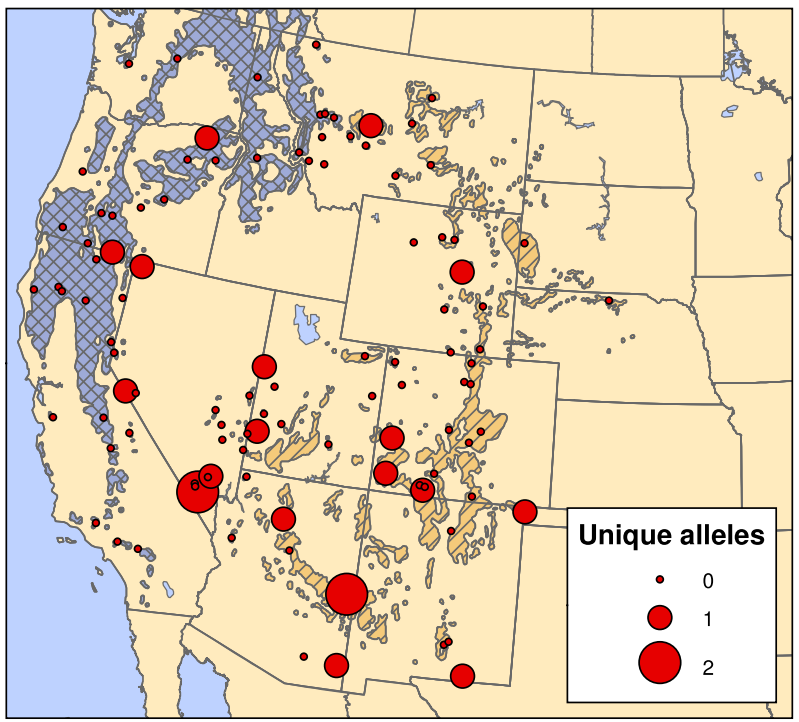

(d)

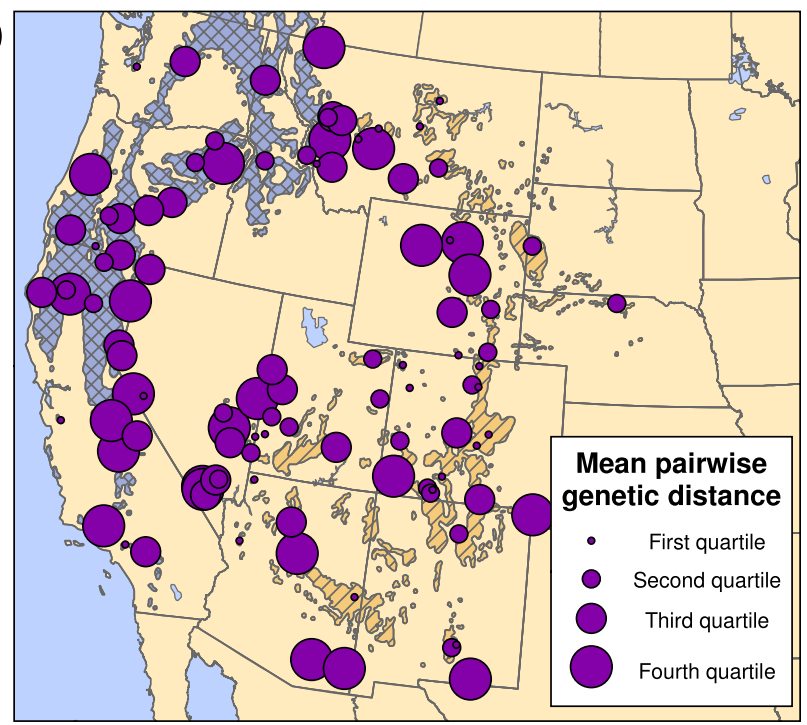

Fig. 3 Pinus ponderosa classifications of a alleles per locus $(A)$, b unique alleles $\left(A_{\mathrm{U}}\right)$, $\mathbf{c}$ inbreeding coefficient $\left(F_{\mathrm{IS}}\right)$, and $\mathbf{d}$ mean pairwise chord distance $\left(D_{\mathrm{C}}\right)$, based on seven polymorphic microsatellite loci

occurred within the Rocky Mountain variety. Populations with the lowest number included isolated disjuncts within the Rocky Mountain variety ( $\# 55,75$, and 103) and populations in the northern part of the Pacific variety (\#1, 14, 21, 28, 30, and 33). Only four populations possessed unique isozyme alleles.

The mean microsatellite observed heterozygosity across ponderosa pine populations $(0.561)$ was less than the mean expected heterozygosity (0.604) (Online Resource 4$)$. Nearly all populations were significantly out of Hardy-Weinberg equilibrium. Widespread inbreeding within ponderosa pine was indicated by a positive mean $F_{\text {IS }}$ of 0.093 across the populations, and by the fact that nearly all populations had positive $F_{\text {IS }}$ values (Online Resource 4). The most highly inbred populations tended to be located in the northern parts of the Pacific variety (Fig. 3c). The isozyme results were similar, with a positive mean $F_{\text {IS }}$ of 0.177 across the populations (Online Resource 5) and with highly inbred populations distributed across the species range (Online Resource 6).

The populations that were the most genetically distinct, based on microsatellite mean pairwise chord genetic distance $\left(D_{\mathrm{C}}\right)$ between that given population and the 103 others (Online Resource 4, Fig. 3d), were isolated disjuncts (\#34, 56,63 , and 66 ). The mean value of mean $D_{\mathrm{C}}$ across populations was 0.452 . For isozymes, the most genetically distinct populations tended to occur in the Sierra Nevada of California, in northern California/southern Oregon, western Montana, and scattered across the southern Rocky Mountains (Online Resource 6).

Ponderosa pine did not exhibit the excess of heterozygosity expected following a recent genetic bottleneck. Instead, we found significant heterozygosity deficiency $(p=0.0017$ for 
microsatellites and $p<0.0001$ for isozymes), suggesting a relatively recent population expansion without immigration (Cornuet and Luikart 1996; Karhu et al. 2006). Many populations exhibited a significant heterozygosity deficiency for microsatellites or for isozymes (Online Resource 4 and 5). All nine STRUCTURE-inferred genetic clusters expressed significant heterozygosity deficiency for both microsatellites and isozymes (Table 4).

Mantel tests revealed evidence of a moderate effect of isolation by distance across all populations for microsatellites $(r=0.08, p=0.001)$, but found no statistical evidence for isozymes $(r=0.017, p=0.266)$.

\section{Group comparisons by variety and isolation}

Most standard measures of genetic variation were significantly different between the two varieties (Table 5a). On average, populations of the Rocky Mountain variety had greater microsatellite allelic richness, number of rare alleles, and observed heterozygosity, as well as higher isozyme allelic richness. On average, populations of the Pacific variety had higher microsatellite expected heterozygosity, inbreeding, and mean pairwise $D_{\mathrm{C}}$ genetic distance. They also had a higher proportion of isozyme polymorphic loci, and greater isozyme observed heterozygosity, expected heterozygosity, and mean pairwise $D_{\mathrm{C}}$ genetic distance.

We detected fewer genetic differences between isolated disjunct and non-disjunct populations (Table $5 \mathrm{~b}$ ). The isolated disjunct populations had, on average, lower microsatellite and isozyme allelic richness and proportion of polymorphic isozyme loci. For both microsatellites and isozymes, the mean pairwise $D_{\mathrm{C}}$ genetic distance was greater for the disjunct populations.

\section{Correlations with geographic variables}

Overall, this geographic assessment indicated small to moderate linear relationships between population-level genetic variation metrics and geographic variables (Table 6). We found a moderate negative relationship between latitude and the number of microsatellite unique alleles and of rare alleles, indicating that populations located farther north had fewer unique and rare alleles. Population elevation was positively associated with allelic richness and number of rare alleles. No isozyme genetic diversity measures were correlated with latitude, but consistent with the microsatellite results, populations at higher elevations had a greater number of rare isozyme alleles. Elevation, however, was negatively correlated with isozyme expected heterozygosity.

We detected fewer significant correlations within the two varieties of ponderosa pine (Online Resource 7). Within the Pacific variety, latitude was correlated negatively with the number of microsatellite rare alleles. Within the Rocky
Mountain variety, latitude was negatively correlated with unique microsatellite alleles and isozyme mean pairwise $D_{\mathrm{C}}$ distance. Elevation was positively correlated with rare isozyme alleles.

\section{Partitioning of genetic variation within regions and races}

The results of the AMOVA of microsatellite variation demonstrated that approximately $30 \%$ of the variation was partitioned among populations $\left(\Phi_{P T}=0.297\right): 21.8 \%$ associated with division of the species into two varieties and $7.9 \%$ associated with populations within the varieties (Table 7). The remaining $70 \%$ occurred within populations. This was less than the amount of among-population variance within each variety $\left(\Phi_{P T}=0.1\right.$ for var. ponderosa and $\Phi_{P T}=0.116$ for var. scopulorum), indicating that approximately $90 \%$ of the microsatellite genetic variation within the varieties occurred within populations rather than among them. The isozyme results were similar, with about $35 \%$ of species-level variation partitioned among populations $\left(\Phi_{P T}=0.345\right)$ rather than within them (Online Resource 8 ). Within varieties, a greater proportion of variation was partitioned within populations (about $75 \%$ ) than among them (about $25 \%$ ). These results are largely consistent with $F_{\mathrm{ST}}$ and $D_{\text {est }}$ estimates of among-population differentiation (Table 2, Online Resource 1). While the STRU CTURE analyses (Fig. 1, Online Resource 2) suggest the existence of important variation within the two varieties, the relatively small proportion of variance assigned by the AMOVA analyses to pre-defined races (with the exception of isozyme variation in var. ponderosa) demonstrates that these racial divisions do not capture this variation well.

\section{Discussion}

\section{Implications for phylogeography}

Patterns of nuclear marker variation across the range of the ponderosa pine complex provide evidence of relatively recent evolutionary processes within and across the species. Specifically, these results reveal genetic signatures of Pleistocene glacial refuges and post-Pleistocene colonization and population expansion, including spatial patterns of diversity and genetic structure associated with putative refugial areas and colonization routes. They also suggest that isolated populations are less genetically diverse and more genetically differentiated than populations that are not isolated. Such findings have important management and conservation implications for this widespread species of great ecological and economic value in western North America.

Large-scale migration and admixture of distinct gene pools within species may result from complex spatiotemporal processes within species (Durand et al. 2009), such as the 
Table 5 Comparison between means of genetic variation statistics for populations within the two varieties of ponderosa pine, and for populations disjunct from or existing within large continuous distributional areas of the species

Differences of means

\begin{tabular}{|c|c|c|c|c|c|c|c|c|c|c|}
\hline & Mean & SD & Min & Max & Mean & $\mathrm{SD}$ & Min & Max & $p$ & $q$ \\
\hline (a) Variety & \multicolumn{4}{|c|}{ var. ponderosa $(n=41)$} & \multicolumn{4}{|c|}{ var. scopulorum $(n=63)$} & & \\
\hline \multicolumn{11}{|l|}{ Microsatellite loci } \\
\hline Allelic richness $(A)$ & 6.98 & 0.77 & 5.43 & 8.71 & 7.63 & 1.27 & 3.43 & 11.14 & $<0.001$ & $<0.001$ \\
\hline Unique alleles $\left(A_{\mathrm{U}}\right)$ & 0.10 & 0.30 & 0 & 1.00 & 0.25 & 0.51 & 0 & 2.00 & 0.057 & 0.057 \\
\hline Rare alleles $\left(A_{\mathrm{R}}\right)$ & 2.28 & 0.62 & 1.14 & 4.00 & 2.86 & 0.77 & 0.57 & 4.86 & $<0.001$ & $<0.001$ \\
\hline Observed heterozygosity $\left(H_{\mathrm{O}}\right)$ & 0.548 & 0.052 & 0.442 & 0.648 & 0.570 & 0.058 & 0.443 & 0.739 & 0.034 & 0.046 \\
\hline Expected heterozygosity $\left(H_{\mathrm{E}}\right)$ & 0.614 & 0.044 & 0.501 & 0.697 & 0.598 & 0.047 & 0.469 & 0.701 & 0.036 & 0.046 \\
\hline Inbreeding $\left(F_{\mathrm{IS}}\right)$ & 0.124 & 0.072 & -0.054 & 0.258 & 0.073 & 0.072 & -0.055 & 0.215 & $<0.001$ & $<0.001$ \\
\hline Mean pairwise $D_{\mathrm{C}}$ & 0.456 & 0.026 & 0.412 & 0.532 & 0.449 & 0.033 & 0.383 & 0.572 & 0.022 & 0.046 \\
\hline Heterozygosity deficiency $\left(H_{\text {def }}\right) p$ value & 0.040 & 0.063 & 0.004 & 0.234 & 0.048 & 0.104 & 0.004 & 0.594 & 0.055 & 0.057 \\
\hline \multicolumn{11}{|l|}{ Isozyme loci } \\
\hline Allelic richness $(A)$ & 1.76 & 0.11 & 1.53 & 2.00 & 1.81 & 0.17 & 1.26 & 2.32 & 0.031 & 0.056 \\
\hline Proportion polymorphic loci $\left(P_{\mathrm{P}}\right)$ & 0.49 & 0.06 & 0.37 & 0.63 & 0.46 & 0.08 & 0.16 & 0.58 & 0.042 & 0.063 \\
\hline Rare alleles $\left(A_{\mathrm{R}}\right)$ & 0.16 & 0.08 & 0 & 0.37 & 0.19 & 0.10 & 0.05 & 0.42 & 0.081 & 0.104 \\
\hline Observed heterozygosity $\left(H_{\mathrm{O}}\right)$ & 0.108 & 0.021 & 0.061 & 0.146 & 0.098 & 0.019 & 0.053 & 0.153 & 0.005 & 0.015 \\
\hline Expected heterozygosity $\left(H_{\mathrm{E}}\right)$ & 0.133 & 0.022 & 0.086 & 0.177 & 0.113 & 0.022 & 0.043 & 0.166 & $<0.001$ & $<0.001$ \\
\hline Inbreeding $\left(F_{\mathrm{IS}}\right)$ & 0.182 & 0.101 & -0.046 & 0.421 & 0.174 & 0.096 & -0.055 & 0.386 & 0.331 & 0.331 \\
\hline Mean pairwise $D_{C}$ & 0.142 & 0.013 & 0.124 & 0.194 & 0.137 & 0.011 & 0.119 & 0.172 & 0.011 & 0.025 \\
\hline Heterozygosity deficiency $\left(H_{\text {def }}\right) p$ value & 0.095 & 0.097 & 0 & 0.313 & 0.070 & 0.110 & 0 & 0.594 & 0.093 & 0.105 \\
\hline (b) Disjunct status & \multicolumn{4}{|c|}{ Not disjunct $(n=59)$} & \multicolumn{4}{|c|}{ Disjunct $(n=45)$} & & \\
\hline \multicolumn{11}{|l|}{ Microsatellite loci } \\
\hline Allelic richness $(A)$ & 7.61 & 1.03 & 5.57 & 11.14 & 7.05 & 1.21 & 3.43 & 9.43 & 0.011 & 0.0945 \\
\hline Unique alleles $\left(A_{\mathrm{U}}\right)$ & 0.14 & 0.39 & 0.00 & 2.00 & 0.27 & 0.50 & 0.00 & 2.00 & 0.076 & 0.1868 \\
\hline Rare alleles $\left(A_{\mathrm{R}}\right)$ & 2.74 & 0.79 & 1.14 & 4.86 & 2.50 & 0.72 & 0.57 & 3.71 & 0.083 & 0.1868 \\
\hline Observed heterozygosity $\left(H_{\mathrm{O}}\right)$ & 0.559 & 0.052 & 0.454 & 0.685 & 0.565 & 0.063 & 0.442 & 0.739 & 0.277 & 0.4155 \\
\hline Expected heterozygosity $\left(H_{\mathrm{E}}\right)$ & 0.605 & 0.042 & 0.513 & 0.685 & 0.603 & 0.051 & 0.469 & 0.701 & 0.501 & 0.501 \\
\hline Inbreeding $\left(F_{\mathrm{IS}}\right)$ & 0.092 & 0.079 & -0.055 & 0.258 & 0.096 & 0.073 & -0.033 & 0.247 & 0.369 & 0.4744 \\
\hline Mean pairwise $D_{\mathrm{C}}$ & 0.445 & 0.026 & 0.383 & 0.509 & 0.460 & 0.035 & 0.412 & 0.572 & 0.021 & 0.0945 \\
\hline Heterozygosity deficiency $\left(H_{\mathrm{def}}\right) p$ value & 0.038 & 0.072 & 0.004 & 0.289 & 0.054 & 0.109 & 0.004 & 0.594 & 0.133 & 0.2394 \\
\hline \multicolumn{11}{|l|}{ Isozyme loci } \\
\hline Allelic richness $(A)$ & 1.83 & 0.14 & 1.58 & 2.32 & 1.74 & 0.16 & 1.26 & 2.16 & 0.002 & 0.018 \\
\hline Proportion polymorphic loci $\left(P_{\mathrm{P}}\right)$ & 0.48 & 0.06 & 0.37 & 0.63 & 0.45 & 0.09 & 0.16 & 0.58 & 0.029 & 0.087 \\
\hline Rare alleles $\left(A_{\mathrm{R}}\right)$ & 0.19 & 0.10 & 0.00 & 0.42 & 0.16 & 0.09 & 0.05 & 0.42 & 0.065 & 0.128 \\
\hline Observed heterozygosity $\left(H_{\mathrm{O}}\right)$ & 0.104 & 0.020 & 0.062 & 0.153 & 0.099 & 0.022 & 0.053 & 0.143 & 0.144 & 0.176 \\
\hline Expected heterozygosity $\left(H_{\mathrm{E}}\right)$ & 0.125 & 0.024 & 0.076 & 0.177 & 0.117 & 0.023 & 0.043 & 0.166 & 0.084 & 0.128 \\
\hline Inbreeding $\left(F_{\mathrm{IS}}\right)$ & 0.180 & 0.098 & -0.055 & 0.382 & 0.174 & 0.098 & -0.046 & 0.421 & 0.305 & 0.305 \\
\hline Mean pairwise $D_{\mathrm{C}}$ & 0.138 & 0.013 & 0.120 & 0.194 & 0.141 & 0.011 & 0.119 & 0.172 & 0.029 & 0.087 \\
\hline Heterozygosity deficiency $\left(H_{\mathrm{def}}\right) p$ value & 0.077 & 0.106 & 0.000 & 0.594 & 0.084 & 0.105 & 0.000 & 0.371 & 0.156 & 0.176 \\
\hline
\end{tabular}

$q$, false discovery rate adjusted $p$-value. Values significant at $\alpha \leq 0.05$ are in italics

responses to the Quaternary ice ages that played an especially important role in determining the current genetic structure of species and populations (Hewitt 2000). During the Pleistocene, however, ponderosa pine is almost entirely absent from the paleoecological record in the west with the exceptions of the Santa Catalina Mountains of southern Arizona and the southern Sierra Nevada in California (Anderson 1989; MacDonald et al. 1998; Van Devender et al. 1987; Van Devender 1990; Anderson 1990), a situation which obscures phylogeographic processes likely to have influenced the evolutionary history of the complex. Because of this dearth of Pleistocene paleoecological data, the locations of ponderosa pine refugia 
Table 6 Correlations between population-level genetic diversity measures and latitude and elevation across the 104 populations of ponderosa pine. Correlation results within the two varieties of the species are available in Online Resource 7

\begin{tabular}{|c|c|c|c|c|c|c|}
\hline & \multicolumn{3}{|l|}{ Latitude } & \multicolumn{3}{|c|}{ Elevation } \\
\hline & $r$ & $p$ value & $q$ & $r$ & $p$ value & $q$ \\
\hline \multicolumn{7}{|l|}{ Microsatellite loci } \\
\hline Allelic richness $(A)$ & -0.121 & 0.219 & 0.438 & 0.224 & 0.022 & 0.088 \\
\hline Unique alleles $\left(A_{\mathrm{U}}\right)$ & -0.230 & 0.019 & 0.076 & 0.060 & 0.545 & 0.634 \\
\hline Rare alleles $\left(A_{\mathrm{R}}\right)$ & -0.301 & 0.002 & 0.015 & 0.352 & $<0.001$ & 0.002 \\
\hline Observed heterozygosity $\left(H_{\mathrm{O}}\right)$ & 0.061 & 0.541 & 0.721 & 0.046 & 0.646 & 0.646 \\
\hline Expected heterozygosity $\left(H_{\mathrm{E}}\right)$ & 0.167 & 0.089 & 0.238 & -0.061 & 0.539 & 0.634 \\
\hline Inbreeding $\left(F_{\mathrm{IS}}\right)$ & -0.002 & 0.981 & 0.981 & -0.148 & 0.135 & 0.359 \\
\hline Mean pairwise $D_{\mathrm{C}}$ & -0.026 & 0.793 & 0.907 & -0.130 & 0.187 & 0.374 \\
\hline Heterozygosity deficiency $\left(H_{\text {def }}\right) p$ value & -0.090 & 0.362 & 0.580 & -0.059 & 0.554 & 0.634 \\
\hline \multicolumn{7}{|l|}{ Isozyme loci } \\
\hline Allelic richness $(A)$ & -0.032 & 0.750 & 0.750 & 0.179 & 0.069 & 0.137 \\
\hline Proportion polymorphic loci $\left(P_{\mathrm{P}}\right)$ & 0.032 & 0.747 & 0.750 & 0.029 & 0.771 & 0.881 \\
\hline Rare alleles $\left(A_{\mathrm{R}}\right)$ & -0.113 & 0.256 & 0.563 & 0.346 & $<0.001$ & 0.001 \\
\hline Observed heterozygosity $\left(H_{\mathrm{O}}\right)$ & 0.129 & 0.193 & 0.563 & -0.186 & 0.058 & 0.137 \\
\hline Expected heterozygosity $\left(H_{\mathrm{E}}\right)$ & 0.202 & 0.040 & 0.317 & -0.374 & $<0.001$ & $<0.001$ \\
\hline Inbreeding $\left(F_{\mathrm{IS}}\right)$ & -0.060 & 0.546 & 0.728 & -0.002 & 0.981 & 0.981 \\
\hline Mean pairwise $D_{\mathrm{C}}$ & -0.105 & 0.290 & 0.563 & -0.035 & 0.723 & 0.881 \\
\hline Heterozygosity deficiency $\left(H_{\text {def }}\right) p$ value & -0.092 & 0.352 & 0.563 & -0.080 & 0.421 & 0.674 \\
\hline
\end{tabular}

$q$, false discovery rate adjusted $p$ value. Values significant at $\alpha \leq 0.05$ are in italics during this period are a matter of debate. The species may have been an important part of montane forest communities south of $35^{\circ} \mathrm{N}$ during the peak of the glaciation, being most common in the Sierra Madre Occidental of northern Mexico (Betancourt et al. 1990). At the same time, it is also possible ponderosa pine persisted in isolated mesic microhabitats
Table 7 Analyses of molecular variance (AMOVAs) of microsatellite data for (1) P. ponderosa and the Pacific and Rocky Mountain varieties, (2) $P$. ponderosa var. ponderosa and the races contained within, and (3) P. ponderosa var. scopulorum and the races contained within; all variance components are significant at $p<0.001$

\begin{tabular}{|c|c|c|c|c|c|c|c|}
\hline Source & $\mathrm{df}$ & SS & MS & Variance & $\%$ & $\Phi$ & Value \\
\hline \multicolumn{8}{|l|}{ P. ponderosa } \\
\hline Among varieties & 1 & 2479.10 & 2479.10 & 1.646 & $21.8 \%$ & $\Phi_{R T}$ & 0.218 \\
\hline $\begin{array}{l}\text { Among populations } \\
\text { within varieties }\end{array}$ & 102 & 2362.94 & 23.17 & 0.597 & $7.9 \%$ & $\Phi_{P R}$ & 0.101 \\
\hline \multirow[t]{2}{*}{ Within populations } & 3009 & $15,997.26$ & 5.32 & 5.316 & $70.3 \%$ & & \\
\hline & & & & & & $\Phi_{P T}$ & 0.297 \\
\hline Total & 3112 & $20,839.29$ & & 7.559 & $100.0 \%$ & & \\
\hline \multicolumn{8}{|c|}{ P. ponderosa var. ponderosa } \\
\hline Among races & 2 & 164.935 & 82.467 & 0.193 & $3.2 \%$ & $\Phi_{R T}$ & 0.032 \\
\hline $\begin{array}{l}\text { Among populations } \\
\text { within races }\end{array}$ & 38 & 680.867 & 17.918 & 0.412 & $6.8 \%$ & $\Phi_{P R}$ & 0.070 \\
\hline \multirow[t]{2}{*}{ Within populations } & 1198 & 6548.613 & 5.466 & 5.466 & $90.0 \%$ & & \\
\hline & & & & & & $\Phi_{P T}$ & 0.100 \\
\hline Total & 1238 & 7394.414 & & 6.072 & $100.0 \%$ & & \\
\hline \multicolumn{8}{|c|}{ P. ponderosa var. scopulorum } \\
\hline Among races & 1 & 66.82 & 66.82 & 0.056 & $1.0 \%$ & $\Phi_{R T}$ & 0.010 \\
\hline $\begin{array}{l}\text { Among populations } \\
\text { within races }\end{array}$ & 61 & 1450.64 & 23.78 & 0.626 & $10.6 \%$ & $\Phi_{P R}$ & 0.107 \\
\hline \multirow[t]{2}{*}{ Within populations } & 1811 & 9448.64 & 5.22 & 5.217 & $88.4 \%$ & & \\
\hline & & & & & & $\Phi_{P T}$ & 0.116 \\
\hline Total & 1873 & $10,966.10$ & & 5.900 & $100.0 \%$ & & \\
\hline
\end{tabular}


farther north than southern New Mexico and Arizona, although no fossil data currently support this hypothesis (Anderson 1989; Rehfeldt 1999a).

Patterns of genetic diversity across the range of the species, along with the current geographic distribution of genetic clusters, may support the hypothesis that ponderosa pine expanded at the end of the Pleistocene from small, as-yet-undetected glacial refugia beyond the known refugial areas of southern Arizona/New Mexico and the southern Sierra Nevada in California. First, several of the genetic clusters are prevalent only outside of these areas. The Rocky Mountain South 3 genetic cluster, for example, appears most closely associated with the isolated populations of southern Nevada, while the Rocky Mountain North 1 genetic cluster is rare south of Colorado (Fig. 1b). The distribution of mitochondrial DNA haplotypes has provided circumstantial evidence of refugia near these areas (the Great Basin and the High Plains, respectively) (Potter et al. 2013), while paleoecological evidence establishes the existence of ponderosa pine in northwestern Wyoming (in an area where it no longer occurs) during a warm interglacial period approximately 127,000 years BP (Baker 1986). Given that the Pleistocene was punctuated by multiple short Holocene-like interglacial periods (Porter 1989), it is possible that ponderosa pine repeatedly retreated to and advanced from isolated favorable microhabitats. Possible locations of these habitats during the most recent glacial maximum (and, conversely, the locations of areas that were colonized later) could be identified by patterns of genetic variation in current populations across the distribution of ponderosa pine. Locations closer to Pleistocene refugia are expected to have greater genetic variation than those colonized later (Hewitt 1996). Microsatellite and isozyme allelic richness (Fig. 3a, Online Resource 6) and isozyme percent polymorphic loci were high in southern Arizona/New Mexico, southern Nevada/Utah, north-central Colorado, northern California/southern Oregon, and central Montana. All these regions also contained at least one unique microsatellite allele (Fig. 3b). Results from a separate mtDNA marker analyses identified all these locations, with the exception of central Montana, as areas that may have harbored glacial refugia (Potter et al. 2013).

Importantly, the results of the STRUCTURE (Fig. 1), clustering (Fig. 2), and genetic variation (Table 5a) analyses appear to demonstrate that the two varieties of ponderosa pine are strongly divided and that they have undergone dissimilar phylogeographic processes. These findings imply that the species consisted of at least two largely unconnected refugia, or groups of refugia, associated with the two varieties, which may have been isolated well before the most recent glacial maximum 18,000 years BP; Lascoux et al. (2004), in fact, estimated that the ponderosa pine varieties have been separated for more than 10,000 generations or 250,000 years. Multiple refugia within each variety are likely to have experienced dissimilar degrees of Pleistocene isolation, leading to varying degrees of genetic differentiation. Genetic clusters with less inferred genetic exchange with others in the same variety, for example, may be associated with more isolated refugia in the Pleistocene. Examples include the Pacific South 3 and Rocky Mountain South 3 genetic clusters (Table 3, Fig. 1a).

Additionally, the significantly lower genetic variation and significantly higher inbreeding within the Pacific variety suggests that the Pleistocene crucible may have been more intense there, potentially in the form of fewer and smaller refugia. Fossil evidence clearly shows that ponderosa pine was present in the southern Sierra Nevada as far back as 45,000 years BP (Cole 1983; Anderson 1990). The results of the current study are consistent with the recent mtDNA haplotype analysis (Potter et al. 2013) in pointing to the Siskiyou and Klamath mountain ranges in northern California and southern Oregon as an additional potential refugial location for Pacific ponderosa pine. These ranges, colloquially known as the "Klamath Knot", were not widely impacted by widespread glaciation and contain extensive floristic diversity (Sawyer 2007). Additionally, pumice fall from volcanic activity in the eastern Cascades, potentially associated with the eruption of Mount Mazama approximately 5700 years ago, appears to have resulted in the reduction in Oregon of ponderosa pine in favor of lodgepole pine, which was in turn replaced again by ponderosa pine over time (Hansen 1942, 1947).

\section{Patterns of within-population genetic variation}

This study identified widespread inbreeding across the range of ponderosa pine, across the species, its genetic clusters, and most of its populations. This pattern is consistent with a signature of long-distance colonization events and subsequent genetic bottlenecks occurring during post-glacial range expansion (Hewitt 1996; Ibrahim et al. 1996; Bialozyt et al. 2006). While we did not detect the signature of a recent genetic bottleneck for ponderosa pine or any of its populations, we did find indications, for the entire species and for most of its populations, of a relatively recent range-wide population expansion that may have followed such an event. This is consistent with the fact that, despite being virtually absent from the preceding paleoecological record, ponderosa pine was widespread across the Southwest by 10,000 to 9000 years BP (Anderson et al. 1999; Van Devender and Spaulding 1979; Van Devender et al. 1987; Anderson 1989; Betancourt 1990) and across nearly all of its current distribution by 3000 to 8000 years ago (Conkle and Critchfield 1988), a rapid expansion that is one of the most remarkable Holocene dispersal events of a western North American conifer (Van Devender et al. 1984).

Somewhat surprisingly, the isolated disjunct populations included in the analysis were not more inbred than those that were not isolated and disjunct (Table 5b). Much of the distribution of the species consists of such populations, many of 
which are located in at higher elevations than their surroundings. Loss of genetic diversity in small and isolated populations of tree species is often associated with genetic drift and inbreeding (Jaramillo-Correa et al. 2009), and is predicted to reduce overall population fitness (Reed and Frankham 2003) and the capacity of populations to adapt to environmental change (Willi et al. 2006). At the same time, marginal ponderosa pine populations appear to encompass significantly lower levels of both microsatellite and isozyme allelic richness, as well as isozyme polymorphism, than interior-range populations, while the populations with the lowest values for several microsatellite genetic diversity statistics were isolated disjuncts. Additionally, pairwise isozyme-related population differentiation was higher for isolated populations, and the most genetically distinct populations were disjuncts. Both sets of findings are consistent with the prediction that withinpopulation genetic diversity should decline and amongpopulation genetic differentiation should increase from the center of a species' geographic range to its periphery (Eckert et al. 2008). We detected no significant difference, however, in microsatellite or isozyme heterozygosity between isolated disjunct and interior-range populations. This may be the result of a mosaic pattern of seedling recruitment, in which only a few maternal trees contribute to each localized patch of seedlings, increasing overall heterozygosity within isolated populations (Hamrick et al. 1989).

\section{Implications for Pinus ponderosa taxonomy}

The taxonomy of the ponderosa pine complex (reviewed in Callaham 2013a) is far from resolved (Kral 1993) in no small part because of conflicting geographic patterns of needle and cone morphology, growth traits, monoterpene content, and isozyme content (reviewed in Conkle and Critchfield 1988), as well as DNA sequence variation (Gernandt et al. 2009). The results of the STRUCTURE (Fig. 1a), NJ phylogram construction (Fig. 2), and ANOVA (Table 7, Online Resource 8) analyses in the current study are consistent with the previous studies (Conkle and Critchfield 1988; Potter et al. 2013) that separate the species into two varieties, Pacific (var. ponderosa) and Rocky Mountain (var. scopulorum). The geographic pattern of STRUCTURE-defined genetic clusters in the current study (when $\mathrm{K}=4$ and 5) may support the additional division of the two varieties into northern and southern races (Online Resource 2), each possibly associated with different Pleistocene glacial refugia. At the same time, the AMOVA analyses confirm that previously proposed racial divisions (e.g., Conkle and Critchfield 1988 and Callaham 2013b) do not explain much of the genetic variation occurring within each of the two varieties, while the phylograms based on microsatellite and isozyme differences between STRU CTURE-defined genetic clusters do not suggest clear racial divisions within the varieties. Patterns of pairwise genetic differentiation between genetic clusters (Table 3) further underscore the widespread recent gene flow (and/or recent common ancestry) among genetic clusters within varieties, but the general lack of gene flow (or recent common ancestry) between the Pacific and Rocky Mountain varieties.

Three populations in central Montana (\#61, 63, and 64) are exceptions to this rule; though they exist in the range of Rocky Mountain ponderosa pine, they primarily consist of gene pools associated with Pacific ponderosa pine (Fig. 1). This demonstrates the existence of west-to-east introgression in this unique area of secondary contact between the varieties. This was corroborated by the fact that trees sampled from these three populations had almost entirely three-needle fascicles, like all var. ponderosa populations but unlike other var. scopulorum populations in the area. In these other local populations, trees had an average of at least $40 \%$ two-needle fascicles. This pattern of west-to-east introgression, however, was not observed in this area using a mitochondrial DNA marker (Potter et al. 2013; Johansen and Latta 2003). Because mtDNA is maternally inherited in most pine species (Neale and Sederoff 1989; Dong and Wagner 1994) and therefore generally dispersed by relatively short-distance seed movement in ponderosa pine (Latta et al. 1998), although longer-distance seed movement has been documented via caching by birds (Lorenz et al. 2008), our findings indicate the existence of at least some contemporary gene flow via wind-dispersed pollen from the Pacific to the Rocky Mountain variety, consistent with the previous findings in the area (Latta and Mitton 1999).

Finally, in keeping with several other analyses (Rehfeldt 1999b; Brayshaw 1997; Lauria 1997; Gernandt et al. 2009; Willyard et al. 2009; Potter et al. 2013), the results of this study do not support separate taxonomic status for Washoe pine, a small-coned form of ponderosa pine identified in a handful of high-elevation locations in northeastern California and northwestern Nevada (Critchfield and Allenbaugh 1965; Critchfield 1984). It has been described as a separate species (P. washoensis H.L. Mason \& Stockw.) and proposed as a variety of ponderosa pine (P. ponderosa var. washoensis (H.L. Mason \& Stockw.) J.R. Haller and N.J. Vivrette). The two Washoe pine populations in this study (\#17 and 18) possess the same genetic cluster composition as other Pacific ponderosa pine populations, although with a higher proportion of the genetic cluster that predominates farther north (Fig. 1, Online Resource 2). This supports the hypothesis that Washoe pine is closely related to the race of ponderosa pine described in the Pacific Northwest (Niebling and Conkle 1990; Critchfield 1984; Rehfeldt 1999b).

\section{Gene conservation implications}

In addition to offering insights into the recent evolutionary history of and the taxonomic relationships within the ponderosa pine complex, the results of this range-wide nuclear 

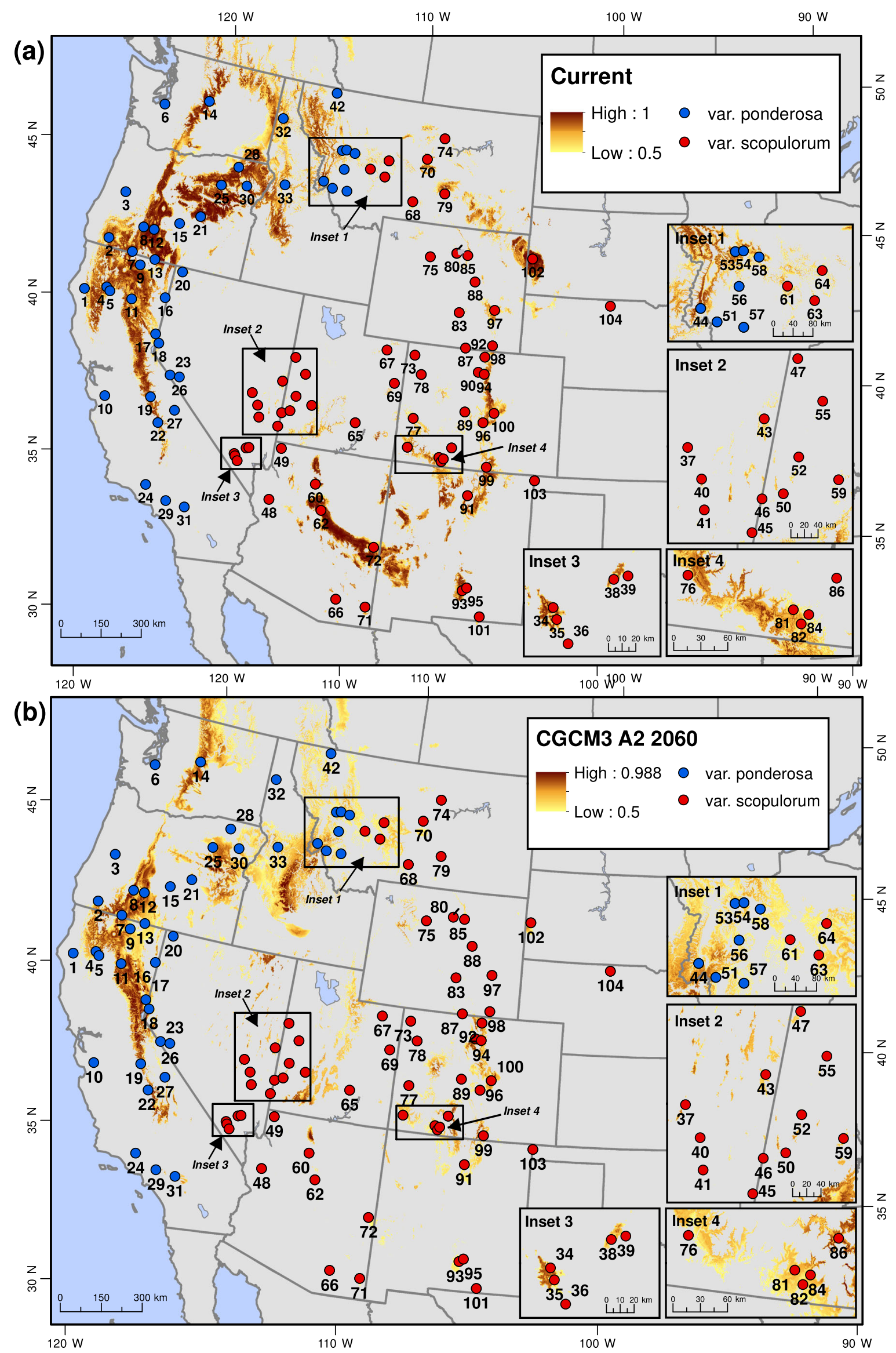
4 Fig. 4 Modeled bioclimate profile of Pinus ponderosa (a) currently and (b) in 2060, based on the CGCM3 global circulation model and A2 emissions scenario (Crookston et al. 2010), overlaid with the locations of the populations included in the current study. The color of the bioclimate profile is associated with the proportion of votes received by a pixel in favor of being within the bioclimate profile

molecular marker study should be applicable for decisionmaking and landscape conservation planning for this widespread and ecologically and economically important tree species. Genetic diversity is an essential component of long-term forest health because it provides a basis for adaptation and resilience to environmental stress and change (Schaberg et al. 2008). In this context, an important goal will be to maintain ponderosa pine genetic material with broad adaptability and high levels of genetic diversity, both on the landscape (in situ) and off-site (ex situ, e.g., seed and pollen banks and clone banks) to be available for the eventual restoration of degraded or extirpated populations.

The results from this study underscore the degree of evolutionary divergence between the two varieties. From a management and conservation perspective, the two varieties therefore should be treated differently in planning and site-based prescriptions when they co-occur within an administrative region. Additionally, it is important to consider the varieties separately in climate-change-associated biogeographic modeling and ecological forecasting (Norris et al. 2006; Rehfeldt et al. 2014b). An analysis of an ensemble of 17 global climate models, for the RCP60 medium-high emissions scenario, indicates that the Rocky Mountain variety should be more vulnerable to climate change, with half its niche space eliminated by 2060 , while losses in niche space for the Pacific variety should be mostly balanced by gains (Rehfeldt et al. 2014b). When overlaid with projections for the CGCM3 global circulation model, A2 emissions scenario (Crookston et al. 2010), 23 of the Rocky Mountain populations included in this analysis are predicted to exist outside currently suitable environmental conditions for ponderosa pine in 2060, compared to 13 Pacific populations (Fig. 4). This increases to 38 and 14 populations, respectively, by 2090 (Online Resource 9); these include many populations, particularly in the Southwest and northern Rockies, that encompass unique alleles, low levels of inbreeding, and/or rare gene pools. As a result, the Rocky Mountain variety should receive more emphasis on climate-change-related management and mitigation activities, although areas within the Pacific variety distribution also deserve attention, including northern Idaho (Fig. 4b). A large portion of the area occupied by the Pacific variety should remain suitable for future climatic conditions, but a much larger proportion of the Rocky Mountain variety may require either introduction of better suited species or conversion to better-adapted genotypes (Rehfeldt et al. 2014c). Artificial reforestation may be required for introductions of ponderosa pine to emergent habitat, for conversion of maladapted forests to productive forests, and for meeting conservation objectives.

Separate gene conservation efforts within the two ponderosa pine varieties should focus on areas containing high genetic variation, including allelic richness and heterozygosity; possessing unique alleles; and encompassing multiple and/or rare gene pools. Within the Pacific variety, this primarily includes areas in northern California/southern Oregon, the central Sierra Nevada, and northeastern Oregon. Across most of the Rocky Mountain variety, microsatellite allelic richness is high, particularly in the Southwest and throughout the Rocky Mountains. Other measures of genetic diversity, however, appear to suggest that gene conservation activities may be most warranted in southern Nevada/ southwestern Utah, southern Arizona and New Mexico, northern Colorado/northern Utah, and southern Colorado. Additionally, the area of contact between the two varieties in central Montana may also deserve attention, as some degree of admixture appears to have occurred here, with the potential for the creation of novel gene combinations in the region. Finally, ponderosa pine gene conservation efforts should incorporate representation of peripheral populations, given that they contain significantly lower allelic richness and greater genetic differentiation than core range populations. These populations may be among the most at risk as a result of climate change because individuals in such small and isolated populations can be less fit as a result of environmental stress and inbreeding, which can increase the probability of population extirpation under changing environmental conditions (Willi et al. 2006).

\begin{abstract}
Acknowledgments The authors thank the natural resource specialists from government agencies who assisted with the identification and collection of samples. The authors thank Doug Page, Connie Millar, and David Charlet for multiple collections; Jody Mello, Rosanna Hanson, Ricardo Hernandez, Pat Guge, Suellen Carroll, Kristin Motz, Courtney Owens, and Sara Trujillo for laboratory analyses; Mark Lesser for sharing the Pinus contorta primer sequences; and Julie Canavin for manuscript preparation assistance. This project was a cooperative effort between the Bureau of Land Management Wyoming and the National Forest Genetics Laboratory of the United States Department of Agriculture (USDA) Forest Service, Forest Management Staff. It was supported in part through Research Joint Venture Agreement 10-JV-11330146-049 between the Southern Research Station of the USDA Forest Service and North Carolina State University. Mention of a trademark, proprietary product, or vendor does not constitute a guarantee or warranty of the product by the USDA and does not imply its approval to the exclusion or other products or vendors that also may be suitable.
\end{abstract}

Data Archiving Statement Microsatellite and isozyme genotypes at all loci for all samples, as well as population names and coordinates, are archived at TreeGenes (http://dendrome.ucdavis.edu/treegenes/) as TGDR035. 


\section{References}

Anderson RS (1989) Development of the southwestern ponderosa pine forests: What do we really know? In: Tecle A, Covington WW, Hamre RH (eds) Multiresource management of ponderosa pine forests. vol General Technical Report RM-185. United States Department of Agriculture, Forest Service, Rocky Mountain Forest and Range Experiment Station, Fort Collins, pp 15-22

Anderson RS (1990) Holocene forest development and paleoclimates within the central Sierra Nevada, California. J Ecol 78(2):470-489

Anderson RS, Hasbargen J, Koehler PA, Feiler EJ (1999) Late Wisconsin and Holocene subalpine forests of the Markagunt Plateau of Utah, southwestern Colorado Plateau, USA. Arct Antarct Alp Res 31(4): 366-378

Baker RG (1986) Sangamonian (questionable) and Wisconsinian paleoenvironments in Yellowstone National Park. Geol Soc Am Bul1 97(6):717-736. doi:10.1130/0016-7606(1986) $97<717$ :sawpiy $>2.0 . c 0 ; 2$

Barton NH, Slatkin M (1986) A quasi-equilibrium theory of the distribution of rare alleles in a subdivided population. Heredity 56:409-415

Betancourt JL (1990) Late Quaternary biogeography of the Colorado Plateau. In: Betancourt JL, Van Devender TR, Martin PS (eds) Packrat middens: the last 40,000 years of biotic change. The University of Arizona Press, Tucson, pp 259-292

Betancourt JL, Van Devender TR, Martin PS (1990) Packrat middens: the last 40,000 years of biotic change. University of Arizona Press, Tucson

Bialozyt R, Ziegenhagen B, Petit RJ (2006) Contrasting effects of long distance seed dispersal on genetic diversity during range expansion. J Evol Biol 19(1):12-20. doi:10.1111/j.1420-9101.2005.00995.x

Boys J, Cherry M, Dayanandan S (2005) Microsatellite analysis reveals genetically distinct populations of red pine (Pinus resinosa Pinaceae). Am J Bot 92(5):833-841

Brayshaw TC (1997) Washoe and ponderosa pines on Promontory Hill near Merritt, B.C., Canada. Ann Naturhist Mus Wien 99B:673-680

Callaham RZ (2013a) Pinus ponderosa: a taxonomic review with five subspecies in the United States. U.S. Department of Agriculture Forest Service, Pacific Southwest Research Station, Albany

Callaham RZ (2013b) Pinus ponderosa: geographic races and subspecies based on morphological variation. U.S. Department of Agriculture Forest Service, Pacific Southwest Research Station, Albany

Cavalli-Sforza LL, Edwards AWF (1967) Phylogenetic analysis: models and estimation procedures. Evolution 21:550-570

Chapman TB, Veblen TT, Schoennagel T (2012) Spatiotemporal patterns of mountain pine beetle activity in the southern Rocky Mountains. Ecology 93(10):2175-2185

Chapuis MP, Estoup A (2007) Microsatellite null alleles and estimation of population differentiation. Mol Biol Evol 24(3):621-631

Cole K (1983) Late Pleistocene vegetation of Kings Canyon, Sierra Nevada, California. Quat Res 19(1):117-129. doi:10.1016/00335894(83)90031-5

Comes HP, Kadereit JW (1998) The effect of quaternary climatic changes on plant distribution and evolution. Trends Plant Sci 3(11):432-438

Conkle MT, Critchfield WB (1988) Genetic variation and hybridization of ponderosa pine. In: Baumgartner DM, Lotan JE (eds) Ponderosa pine: the species and its management. Washington State University Cooperative Extension, Pullman, pp 27-43

Conkle MT, Hodgskiss PD, Nunnally LB, Hunter SC (1982) Starch Gel electrophoresis of conifer seeds: a laboratory manual. Pacific Southwest Forest and Range Experiment Station, United States Department of Agriculture Forest Service, Berkeley

Cornuet JM, Luikart G (1996) Description and power analysis of two tests for detecting recent population bottlenecks from allele frequency data. Genetics 144(4):2001-2014
Crawford NG (2010) SMOGD: software for the measurement of genetic diversity. Mol Ecol Resour 10(3):556-557. doi:10.1111/j.17550998.2009.02801.x

Critchfield WB (1984) Crossability and relationships of Washoe pine. Madrono 31(3):144-170

Critchfield WB, Allenbaugh GL (1965) Washoe pine on the Bald Mountain Range, California. Madrono 18:63-64

Critchfield WB, Little EL (1966) Geographic distribution of the pines of the world. United States Department of Agriculture Forest Service, Washington

Crookston NL, Rehfeldt GE, Dixon GE, Weiskittel AR (2010) Addressing climate change in the forest vegetation simulator to assess impacts on landscape forest dynamics. For Ecol Manag 260(7): 1198-1211. doi:10.1016/j.foreco.2010.07.013

Dempster AP, Laird NM, Rubin DB (1977) Maximum likelihood from incomplete data via the EM algorithm. J R Stat Soc Ser B-Methodol 39(1):1-38

Dong JS, Wagner DB (1994) Paternally inherited chloroplast polymorphism in Pinus: Estimation of diversity and population subdivision, and tests of disequilibrium with a maternally inherited mitochondrial polymorphism. Genetics 136(3):1187-1194

Durand E, Jay F, Gaggiotti OE, Francois O (2009) Spatial inference of admixture proportions and secondary contact zones. Mol Biol Evol 26(9):1963-1973. doi:10.1093/molbev/msp106

Dvorak WS, Potter KM, Hipkins VD, Hodge GR (2009) Genetic diversity and gene exchange in Pinus oocarpa, a Mesoamerican pine with resistance to the pitch canker fungus (Fusarium circinatum). Int $\mathrm{J}$ Plant Sci 170(5):609-626. doi:10.1086/597780

Eckert CG, Samis KE, Lougheed SC (2008) Genetic variation across species' geographical ranges: the central-marginal hypothesis and beyond. Mol Ecol 17(5):1170-1188

Elsik CG, Williams CG (2001) Families of clustered microsatellites in a conifer genome. Mol Gen Genomics 265(3):535-542

Elsik CG, Minihan VT, Hall SE, Scarpa AM, Williams CG (2000) Lowcopy microsatellite markers for Pinus taeda L. Genome 43(3):550 555

Eriksson G, Namkoong G, Roberds JH (1993) Dynamic gene conservation for uncertain futures. For Ecol Manag 62(1-4):15-37

ESRI (2006) ArcMap 9.2. Environmental Systems Research Institute Inc., Redlands, California

Evanno G, Regnaut S, Goudet J (2005) Detecting the number of clusters of individuals using the software STRUCTURE: a simulation study. Mol Ecol 14(8):2611-2620

Excoffier L, Smouse PE, Quattro JM (1992) Analysis of molecular variance inferred from metric distances among DNA haplotypes: Application to human mitochondrial DNA restriction data. Genetics 131(2):479-491

Farjon A (1984) Pines: drawings and descriptions of the genus Pinus. E.J. Brill, Leiden

Felsenstein J (2005) PHYLIP (Phylogeny Inference Package), version 3.6. Department of Genome Sciences, University of Washington, Seattle

Gernandt DS, Hernandez-Leon S, Salgado-Hernandez E, de la Rosa JAP (2009) Phylogenetic relationships of Pinus subsection Ponderosae inferred from rapidly evolving cpDNA regions. Syst Bot 34(3):481491

Gibson JP, Hamrick JL (1991) Genetic diversity and structure in Pinus pungens (Table Mountain pine) populations. Can J For Res-Revue Can De Rech Forestiere 21(5):635-642

Goudet J (1995) FSTAT (version 1.2): a computer program to calculate Fstatistics. J Hered 86(6):485-486

Hale ML, Burg TM, Steeves TE (2012) Sampling for microsatellite-based population genetic studies: 25 to 30 individuals per population is enough to accurately estimate allele frequencies. Plos One 7(9). doi: 10.1371/journal.pone.0045170 
Haller JR (1965) The role of 2-needle fascicles in the adaptation and evolution of ponderosa pine. Brittonia 17(4):354-382

Hamrick JL, Blanton HM, Hamrick KJ (1989) Genetic structure of geographically marginal populations of ponderosa pine. Am J Bot 76(11):1559-1568. doi:10.2307/2444394

Hansen HP (1942) The influence of volcanic eruptions upon postPleistocene forest succession in Central Oregon. Am J Bot 29(3): 214-219. doi:10.2307/2437672

Hansen HP (1947) Postglacial vegetation of the northern Great Basin. Am J Bot 34(3):164-171. doi:10.2307/2437371

Heuertz M, Hausman JF, Hardy OJ, Vendramin GG, Frascaria-Lacoste N, Vekemans X (2004) Nuclear microsatellites reveal contrasting patterns of genetic structure between western and southeastern European populations of the common ash (Fraxinus excelsior L.). Evolution 58(5):976-988

Hewitt GM (1996) Some genetic consequences of ice ages, and their role in divergence and speciation. Biol J Linn Soc 58(3):247-276

Hewitt GM (2000) The genetic legacy of the quaternary ice ages. Nature 405(6789):907-913

Hoff RJ (1988) Susceptibility of ponderosa pine to the needle case fungus Lophodermium baculiferum. U.S. Department of Agriculture Forest Service, Intermountain Research Station, Ogden

Huff DR, Peakall R, Smouse PE (1993) RAPD variation within and among natural populations of outcrossing buffalograss (Buchloe dactyloides (Nutt.) Engelm.). Theor Appl Genet 86(8):927-934. doi:10.1007/bf00211043

Ibrahim KM, Nichols RA, Hewitt GM (1996) Spatial patterns of genetic variation generated by different forms of dispersal during range expansion. Heredity 77:282-291

Jakobsson M, Rosenberg NA (2007) CLUMPP: a cluster matching and permutation program for dealing with label switching and multimodality in analysis of population structure. Bioinformatics 23(14):1801-1806. doi:10.1093/bioinformatics/btm233

Jaramillo-Correa JP, Beaulieu J, Khasa DP, Bousquet J (2009) Inferring the past from the present phylogeographic structure of North American forest trees: seeing the forest for the genes. Can J For Res-Revue Can De Rech Forestiere 39(2):286-307. doi:10.1139/ x08-181

Johansen AD, Latta RG (2003) Mitochondrial haplotype distribution, seed dispersal and patterns of postglacial expansion of ponderosa pine. Mol Ecol 12(1):293-298

Jorgensen SM, Hamrick JL (1997) Biogeography and population genetics of whitebark pine, Pinus albicaulis. Can J For Res 27(10):1574 1585

Jost L (2008) $\mathrm{G}_{\mathrm{ST}}$ and its relatives do not measure differentiation. Mol Ecol 17(18):4015-4026. doi:10.1111/j.1365-294X.2008.03887.x

Kalinowski ST, Taper ML (2006) Maximum likelihood estimation of the frequency of null alleles at microsatellite loci. Conserv Genet 7(6): 991-995. doi:10.1007/s10592-006-9134-9

Karhu A, Vogl C, Moran GF, Bell JC, Savolainen O (2006) Analysis of microsatellite variation in Pinus radiata reveals effects of genetic drift but no recent bottlenecks. J Evol Biol 19(1):167-175

Kitchen SG (2010) Historic Fire Regimes of Eastern Great Basin (USA) Mountains Reconstructed from Tree Rings. Ph.D. Dissertation, Brigham Young University, Provo, Utah

Kral R (1993) Pinus. In: Flora of North America Editorial Committee (ed) Flora of North America North of Mexico, vol Pteridophytes and Gymnosperms, Vol. 2. Oxford University Press, New York, pp 373-398

La Farge T (1975) Genetic differences in stem form of ponderosa pine grown in Michigan. Silvae Genet 23:211-213

Lascoux M, Palme AE, Cheddadi R, Latta RG (2004) Impact of Ice Ages on the genetic structure of trees and shrubs. Philos T Roy Soc B 359(1442):197-207. doi:10.1098/rstb.2003.1390
Latta RG, Mitton JB (1999) Historical separation and present gene flow through a zone of secondary contact in ponderosa pine. Evolution 53(3):769-776

Latta RG, Linhart YB, Fleck D, Elliot M (1998) Direct and indirect estimates of seed versus pollen movement within a population of ponderosa pine. Evolution 52(1):61-67

Lauria F (1997) The taxonomic status of Pinus washoensis H. Mason \& Stockw. (Pinaceae). Ann Naturhist Mus Wien 99:655-671

Lesser MR, Parchman TL, Buerkle CA (2012) Cross-species transferability of SSR loci developed from transciptome sequencing in lodgepole pine. Mol Ecol Resour 12(3):448-455. doi:10.1111/j. 1755-0998.2011.03102.x

Libiger O, Nievergelt CM, Schork NJ (2009) Comparison of genetic distance measures using human SNP genotype data. Hum Biol 81(4):389-406

Liewlaksaneeyanawin C, Ritland CE, El-Kassaby YA, Ritland K (2004) Single-copy, species-transferable microsatellite markers developed from loblolly pine ESTs. Theor Appl Genet 109(2):361-369

Littell JS, McKenzie D, Peterson DL, Westerling AL (2009) Climate and wildfire area burned in western U. S. ecoprovinces, 1916-2003. Ecol Appl 19(4):1003-1021. doi:10.1890/07-1183.1

Little EL (1971) Atlas of United States Trees. Volume 1. Conifers and Important Hardwoods. Washington, D.C

Little EL (1979) Checklist of United States Trees (Native and Naturalized). United States Department of Agriculture, Washington

Lorenz TJ, Aubry C, Shoal R (2008) A review of the literature on seed fate in whitebark pine and the life history traits of Clark's nutcracker and pine squirrels. United States Department of Agriculture Forest Service, Pacific Northwest Research Station, Portland

MacDonald GM, Cwynar LC, Whitlock C (1998) The late quaternary dynamics of pines in northern North America. In: Richardson DM (ed) Ecology and biogeography of Pinus. Cambridge University Press, Cambridge, pp 122-136

McLachlan JS, Clark JS, Manos PS (2005) Molecular indicators of tree migration capacity under rapid climate change. Ecology 86(8): 2088-2098

Meddens AJH, Hicke JA, Ferguson CA (2012) Spatiotemporal patterns of observed bark beetle-caused tree mortality in British Columbia and the western United States. Ecol Appl 22(7):1876-1891

Mitton JB, Ferrenberg SM (2012) Mountain pine beetle develops an unprecedented summer generation in response to climate warming. Am Nat 179(5):E163-E171. doi:10.1086/665007

Moritz C (1994) Defining evolutionarily significant units for conservation. Trends Ecol Evol 9(10):373-375

Neale DB, Sederoff RR (1989) Paternal inheritance of chloroplast DNA and maternal inheritance of mitochondrial DNA in loblolly pine. Theor Appl Genet 77(2):212-216

Niebling CR, Conkle MT (1990) Diversity of Washoe pine and comparisons with allozymes of ponderosa pine races. Can J For Res-Revue Can De Rech Forestiere 20(3):298-308. doi:10.1139/x90-044

Norris JR, Jackson ST, Betancourt JL (2006) Classification tree and minimum-volume ellipsoid analyses of the distribution of ponderosa pine in the western USA. J Biogeogr 33(2):342-360

O'Connell LM, Ritland K, Thompson SL (2008) Patterns of post-glacial colonization by western redcedar (Thuja plicata, Cupressaceae) as revealed by microsatellite markers. Botany 86(2):194-203. doi:10. 1139/b07-124

Oliver WW, Ryker RA (1990) Ponderosa Pine. In: Burns RM, Honkala BH (eds) Silvics of North America: 1. Conifers, vol 1. Agricultural Handbook 654. U.S. Department of Agriculture Forest Service, Washington

Peakall R, Smouse PE (2006) GENALEX 6: genetic analysis in Excel. Population genetic software for teaching and research. Mol Ecol Notes 6(1):288-295. doi:10.1111/j.1471-8286.2005.01155.x

Pearson RG (2006) Climate change and the migration capacity of species. Trends Ecol Evol 21(3):111-113. doi:10.1016/j.tree.2005.11.022 
Peloquin RL (1984) The identification of three-species hybrids in the ponderosa pine complex. Southw Nat 29(1):115-122. doi:10.2307/ 3670776

Perry JP (1991) The Pines of Mexico and Central America. Timber Press, Portland

Piry S, Luikart G, Cornuet JM (1999) BOTTLENECK: a computer program for detecting recent reductions in the effective population size using allele frequency data. J Hered 90(4):502-503

Pitel JA, Cheliak WM (1984) Effect of extraction buffers on characterization of isoenzymes from vegetative tissues of five conifer species: a user's manual. Agriculture Canada, Canadian Forestry Service, Petawawa National Forestry Institute, Chalk River

Porter SC (1989) Some geological implications of average quaternary glacial conditions. Quat Res 32(3):245-261. doi:10.1016/00335894(89)90092-6

Potter KM, Jetton RM, Dvorak WS, Hipkins VD, Rhea R, Whittier WA (2012) Widespread inbreeding and unexpected geographic patterns of genetic variation in eastern hemlock (Tsuga canadensis), an imperiled North American conifer. Conserv Genet 13(2):475-498. doi: 10.1007/s10592-011-0301-2

Potter KM, Hipkins VD, Mahalovich MF, Means RE (2013) Mitochondrial DNA haplotype distribution patterns in Pinus ponderosa (Pinaceae): range-wide evolutionary history and implications for conservation. Am J Bot 100(8):1562-1579. doi:10.3732/ ajb.1300039

Pritchard JK, Stephens M, Donnelly P (2000) Inference of population structure using multilocus genotype data. Genetics 155(2):945-959

Provan J, Bennett KD (2008) Phylogeographic insights into cryptic glacial refugia. Trends Ecol Evol 23(10):564-571. doi:10.1016/j.tree. 2008.06.010

Raymond M, Rousset F (1995) Genepop (version-1.2): population genetics software for exact tests and ecumenicism. J Hered 86(3):248249

Read RA (1980) Genetic variation in seedling progeny of ponderosa pine provenances vol Forest Science Monograph 23. Society of American Foresters, Washington

Read RA (1983) Ten-year performance of ponderosa pine provenances in the great plains of North America. U.S. Department of Agriculture, Forest Service, Rocky Mountain Forest and Range Experiment Station, Fort Collins

Reed DH, Frankham R (2003) Correlation between fitness and genetic diversity. Conserv Biol 17(1):230-237

Rehfeldt GE (1990) Genetic differentiation among populations of Pinus ponderosa from the upper Colorado River basin. Bot Gaz 151(1): $125-137$

Rehfeldt GE (1991) A model of genetic variation for Pinus ponderosa in the Inland Northwest (U.S.A.): applications in gene resource management. Can J For Res 21(10):1491-1500

Rehfeldt GE (1993) Genetic variation in the Ponderosae of the Southwest. Am J Bot 80(3):330-343

Rehfeldt GE (1999a) Systematics and genetic structure of Ponderosae taxa (Pinaceae) inhabiting the mountain islands of the Southwest. Am J Bot 86(5):741-752

Rehfeldt GE (1999b) Systematics and genetic structure of Washoe pine: applications in conservation genetics. Silvae Genet 48(3-4):167173

Rehfeldt GE, Wilson BC, Wells SP, Jeffers RM (1996) Phytogeographic, taxonomic, and genetic implications of phenotypic variation in the Ponderosae of the Southwest. Southwest Nat 41(4):409-418

Rehfeldt GE, Crookston NL, Warwell MV, Evans JS (2006) Empirical analyses of plant-climate relationships for the western United States. Int J Plant Sci 167(6):1123-1150

Rehfeldt GE, Leites LP, St Clair JB, Jaquish BC, Saenz-Romero C, Lopez-Upton J, Joyce DG (2014a) Comparative responses to climate in the varieties of Pinus ponderosa and Pseudotsuga menziesii: clines in growth potential. For Ecol Manag 324:138-146
Rehfeldt GE, Leites LP, St Clair JB, Jaquish BC, Saenz-Romero C, Lopez-Upton J, Joyce DG (2014b) Comparative responses to climate in the varieties of Pinus ponderosa and Pseudotsuga menziesii: realized climate niches. For Ecol Manag 324:126-137

Rehfeldt GE, Leites LP, St Clair JB, Jaquish BC, Saenz-Romero C, Lopez-Upton J, Joyce DG (2014c) Comparative responses to climate in the varieties of Pinus ponderosa and Pseudotsuga menziesii: reforestation. For Ecol Manag 324:147-157

Saitou N, Nei M (1987) The neighbor-joining method: a new method for reconstructing phylogenetic trees. Mol Biol Evol 4(4):406-425

SAS Institute Inc. (2008) The SAS System for Windows, Version 9.2. Cary, North Carolina

Sawyer JO (2007) Why are the Klamath Mountains and adjacent North Coast floristically diverse? Fremontia 35(3):3-11

Schaberg PG, DeHayes DH, Hawley GJ, Nijensohn SE (2008) Anthropogenic alterations of genetic diversity within tree populations: implications for forest ecosystem resilience. For Ecol Manag 256(5):855-862. doi:10.1016/j.foreco.2008.06.038

Schmidtling RC, Hipkins VD (1998) Genetic diversity in longleaf pine (Pinus palustris): influence of historical and prehistorical events. Can J For Res-Revue Can De Rech Forestiere 28(8):1135-1145. doi:10.1139/cjfr-28-8-1135

Slatkin M (1987) Gene flow and the geographic structure of natural populations. Science 236(4803):787-792

Smith RH (1977) Monoterpenes of ponderosa pine xylem resin in western United States. U.S. Department of Agriculture, Forest Service, Washington

Smith RH, Peloquin RL, Passof PC (1969) Local and regional variation in the monoterpenes of ponderosa pine wood oleoresin. U.S. Department of Agriculture, Forest Service, Pacific Southwest Forest and Range Experiment Station, Berkeley

Squillace AE, Silen RR (1962) Racial variation in ponderosa pine. For Sci Monogr 2(2):1-27

Sturgeon KB (1979) Monoterpene variation in ponderosa pine xylem resin related to western pine beetle predation. Evolution 33(3): 803-814. doi:10.2307/2407647

Taberlet P, Fumagalli L, Wust-Saucy AG, Cosson JF (1998) Comparative phylogeography and postglacial colonization routes in Europe. Mol Ecol 7(4):453-464

Takezaki N, Nei M (1996) Genetic distances and reconstruction of phylogenetic trees from microsatellite DNA. Genetics 144(1):389-399

United States Department of Agriculture Forest Service (2012) National Forest Genetics Laboratory, Standard Operating Procedures. National Forest Genetics Laboratory, United States Department of Agriculture Forest Service, Placerville, California

Van Devender TR (1990) Late Quaternary vegetation and climate of the Chihuahuan desert, United States and Mexico. In: Betancourt JL, Van Devender TR, Martin PS (eds) Packrat middens: the last 40,000 years of biotic change. The University of Arizona Press, Tucson, pp 104-132

Van Devender TR, Spaulding WG (1979) Development of vegegation and climate in the southwestern United States. Science 204(4394): 701-710. doi:10.1126/science.204.4394.701

Van Devender TR, Betancourt JL, Wimberly M (1984) Biogeographic implications of a packrat midden sequence from the Sacramento Mountains, south-central New Mexico. Quat Res 22(3):344-360. doi:10.1016/0033-5894(84)90028-0

Van Devender TR, Thompson RS, Betancourt JL (1987) Vegetation history of the deserts of southwestern North America: the nature and timing of the late Wisconsin-Holocene transition. In: Ruddiman WF, Wright HE Jr (eds) North America and adjacent oceans during the last deglaciation, vol the geology of north america, v. K-3. Geological Society of America, Boulder, pp 323-352

Van Haverbeke DF (1986) Genetic variation in ponderosa pine: a 15-year test of provenances in the great plains. U.S. Department of 
Agriculture, Forest Service, Rocky Mountain Forest and Range Experiment Station, Fort Collins

Wang C-W (1977) Genetics of ponderosa pine. U.S. Department of Agriculture, Forest Service, Washington

Weidman RH (1939) Evidences of racial influence in a 25-year test of ponderosa pine. J Agric Res 59:0855-0887

Weir BS, Cockerham CC (1984) Estimating F-statistics for the analysis of population structure. Evolution 38(6):1358-1370

Wells OO (1964) Geographic variation in ponderosa pine: I. The ecotypes and their distribution. Silvae Genet 13(4):89-103

Whitlock C, Shafer SL, Marlon J (2003) The role of climate and vegetation change in shaping past and future fire regimes in the northwestern US and the implications for ecosystem management. For Ecol Manag 178(1-2):5-21. doi:10.1016/s0378-1127(03)00051-3
Willi Y, Van Buskirk J, Hoffmann AA (2006) Limits to the adaptive potential of small populations. Annu Rev Ecol Evol Syst 37:433458

Willyard A, Cronn R, Liston A (2009) Reticulate evolution and incomplete lineage sorting among the ponderosa pines. Mol Phylogenet Evol 52(2):498-511. doi:10.1016/j.ympev.2009.02.011

Wofford AM, Finch K, Bigott A, Willyard A (2014) A set of plastid loci for use in multiplex fragment length genotyping for intraspecific variation in Pinus (Pinaceace). Appl Plant Sci 2(5):XXX

Wright JW, Lemmien WA, Bright JN (1969) Early growth of ponderosa pine ecotypes in Michigan. For Sci 15(2):121-129 